\title{
Is Governance Related to Investment Performance and Asset Allocation? Empirical Evidence from Swiss Pension Funds
}

\author{
Manuel Ammann $^{a}$ and Christian Ehmann ${ }^{a}$
}

JEL-Classification: G11, G19, G23, J32

Keywords: pension fund governance, investment performance, Swiss occupational pension plans

\section{SUMMARY}

This study investigates the relationship between governance, investment performance and asset allocation of pension funds in Switzerland. Our sample includes survey data from 139 Swiss occupational pension plans for which we develop a governance metric comprising attributes of organisational design, management incentives, target setting, investment strategy, investment processes, risk management, monitoring, and transparency. We find empirical evidence that pension fund governance is positively related to excess returns, benchmark outperformance and Sharpe ratios. Pension funds in the top governance quartile outperform those in the bottom quartile by approximately $1 \%$ in terms of average excess returns and benchmark deviation. Furthermore, our study results indicate that asset allocation decisions are not related to governance, but rather to institutional factors.

a University of St. Gallen, Swiss Institute of Banking and Finance, Rosenbergstrasse 52, 9000 St. Gallen, Switzerland. Phone+41-71-224-70-80. E-mail: manuel.ammann@unisg.ch. We would like to thank Andreas Zingg, Christian Gast, Christian Obrist, Kristian Blickle, Hanspeter Konrad and the Swiss Pension Fund Association (ASIP) for their support and their helpful comments. Blackrock Asset Management Switzerland AG is gratefully acknowledged for financing the pension fund survey. 


\section{Introduction}

Switzerland has one of the largest occupational pension systems in Europe insuring more than 3.9 million members at the end of 2013. Total assets held by registered Swiss pension schemes exceeded CHF 720 billion, equalling approximately $113 \%$ of the country's GDP of 2013 (Swiss Federal Statistical Office, 2015). Consequently, governance weaknesses in pension fund management can have systemic implications. In theory, sound governance structures should be associated with better plan performance. Pension funds with efficient management organisations, structured investment processes and comprehensive risk management systems should be able to achieve superior investment performance at the benefit of their members (e.g., through well-qualified trustees, superior asset manager selection procedures, lower asset management costs, or more comprehensive and sophisticated risk management systems, to mention only a few factors).

Academic literature on this topic is very scarce, however. While a number of authors have addressed best-practice principles in pension fund governance (e.g., such as Albrecht, Shamsub, and Giannatasio, 2007; Clark and Urwin, 2008, 2010; Clapman, 2007; Clark, Caerlewy-Smith, and Marshall, 2006; Harper, 2008; Hess, 2005; Impavido, 2002; Jackowicz and Kowalewski, 2012; Mitchell and Hsin, 1997; OECD, 2006, 2009, 2011; YANG and МiтcheLL, 2008; and Yermo and STEwart, 2008), empirical research about such governance structures and their associations with investment performance has gained less attention. Ambachtsheer, Capelle, and Scheibelhut (1998) and AmbaCHTSHEER and EzRa (1998) were among the first scholars who investigated this relationship with empirical data. By means of a questionnaire, the authors find a positive correlation between governance quality, as proxied by their "CEO Score", and investment performance. AmbaChtsheEr, Capelle, and Lum (2008) confirm those results with a more comprehensive dataset in a follow-on study. The authors find that "good-quality" pension funds outperformed "bad-quality" funds by around 200 basis points per year. Since their score metric is reported based on the self-perception of senior pension fund executives, the authors' governance quality measure is not entirely objective, however. More recent empirical studies have focused on more objective governance metrics, such as board composition, ownership structures, and pension fund activism. JACKOWICZ and KowALEWSKI (2012), for example, investigate the effect of certain board member characteristics on risk-adjusted pension fund performance. Studying a sample of defined contribution plans in Poland, the authors find that the number of outsiders on trustee boards as well as the age and the educational background of the trustees is related to the funds' risk-adjusted return on invested assets. 
Although Switzerland has one of the world's largest occupational pension systems, empirical literature on Swiss pension fund governance is almost nonexisting. To this end, the only study that empirically investigates the relationship between pension fund governance and investment performance in Switzerland is provided by AMMANN and ZINGG (2010). To proxy governance quality, the authors employ a questionnaire that asks Swiss pension fund executives about objectively measurable criteria that are based on verifiable facts. While they find a positive relationship between governance and performance, their study is confined to a very narrow time window and to only one performance measure: the "net value added". This study therefore fills the gap in the literature and extends the work of AMMANN and ZINGG (2010) in three important ways: First, we investigate to what extent governance factors affect performance indirectly through asset allocation decisions. Second, our investigation takes into account the scope of the pension funds' risk management practices, which have become of central interest in the aftermath of the global financial crisis. Third, we use a much greater variety of investment performance measures including risk-adjusted return measures as well as relative performance measures (i.e., benchmark deviations). Additionally, we extend the return examination window to three years, using annual investment performance data from 2010 to 2012. We hence contribute to both the empirical literature on pension fund governance and the literature on the objective evaluation of such governance structures in general.

Since neither historical performance data nor data about the governance structures of Swiss pension funds is publicly available, we collect the information via a proprietary survey. We thereby focus on six different governance areas: 1) organisational design, 2) management incentives, 3) target setting and investment strategy, 4) investment processes, 5) risk management, and 6) managerial transparency. Our proprietary dataset contains data from 139 entities, covering almost $43 \%$ of total assets of the Swiss pension universe as of the end of 2012. While previous studies have measured pension fund governance quality mostly with rather subjective measures (e.g., such as self-perceptions or opinions of senior managers, trustees or CEOs), our survey solely includes assessment criteria that are based on objectively quantifiable facts. To assess the sample plans' governance structures in the most objective way, we create the Swiss Pension Fund Governance Score (G-SCORE). The G-SCORE consists of 6 individual sub-scores that cover the above-defined governance areas and is based on the answers of the responding entities. To relate governance to investment performance, we run multivariate regressions using four different portfolio performance metrics as dependent variables. We thereby control for 
institutional factors such as fund size, fund type, plan model, legal form, risk coverage, internal cost structures and the ratio of active plan members to pension beneficiaries.

Our analysis shows that pension fund governance is positively related to the surveyed plans' realised performance of the years 2010-2012. We find that the pension funds of the top G-SCORE quartile outperform those of the bottom quartile by approximately $1 \%$ in terms of average excess returns and passive benchmark deviation. Our investigation furthermore indicates that asset allocation decisions are mainly independent of the prevailing pension fund governance structures, but rather linked to institutional factors (e.g., such as fund size or legal form).

The remainder of this paper is structured as follows: In section 2, we develop an objective governance metric for Swiss occupational pension plans: the Swiss Pension Fund Governance Score (G-SCORE). section 3 explains the performance metrics that are used for the empirical analysis. section 4 presents the econometric model and the control variables beyond governance. Section 5 evaluates the current governance state of the pension funds in our sample and describes the results of the survey. Section 6 presents the empirical findings while section 7 concludes the main results.

\section{Swiss Pension Fund Governance Score (G-SCORE)}

To evaluate pension fund governance structures objectively and comprehensively, we develop the Swiss Pension Fund Governance Score (G-SCORE). The G-SCORE is methodologically related to corporate governance indices that aggregate individual firm governance attributes cumulatively (e.g., also see Ammann, Oesch, and Schmid, 2011, 2013; Bebchuck and Cohen, 2005; Bebchuck, Cohen, and Ferrell, 2008; Brown and Caylor, 2006; GomPERS, IshiI, and METrick, 2003). It draws from previous empirical research findings and, to some extent, best-practice considerations from the academic literature. While we do not claim that the theoretical literature recommendations are necessarily in line with "good" governance due to contradictory empirical evidence for certain score components, we take them as practical reference points for our valuation framework. Although many of the score constituents might theoretically be desirable from a governance point of view, we do not state that occupational pension funds should apply or pursue them in order to improve their governance quality. Neither do we postulate how governance structures should optimally look like. In fact, some of the elements 
that are included in our scoring model are discussed rather controversially in the literature since empirical evidence is contradictory. This particularly pertains to components such as the pursuit of active tactical asset allocation and the design of compensation structures for trustee board members. Our study instead aims at detecting those factors that are potentially related to plan performance and asset allocation decisions.

While previous authors have proxied governance quality with rather subjective metrics, we constrain ourselves to entirely objective factors that are investigated by means of a standardised survey which was sent by mail to Swiss occupational pension funds. For each answer that is deemed to be theoretically desirable from a governance point of view, a pension fund receives 1 point on the G-SCORE. Otherwise, a fund receives 0 points. Consequently, a high score is associated with a comprehensive or "theoretically desirable" governance structure.

Taking a holistic view on pension fund governance, we create 6 sub-scores as well as an overall composite score. The 6 sub-scores evaluate pension fund governance in terms of their organisational design (ORGA Score), management objectives setting (MANO Score), target setting and investment strategy definition (TSIS Score), investment processes (INVP Score), risk management procedures (RIMA Score), and the degree of managerial transparency (MOTR Score). The composite G-SCORE is computed as the sum of all individual sub-scores. The items included in the 6 sub-scores are shown below. The detailed explanations about the construction of the 6 sub-scores are comprehensively described in the appendix of this paper.

The first sub-score assesses a pension fund's governance structure with respect to its organisational setup and responsibility allocation. Our Organisation Score (ORGA) can assume values between 0 and 10. A high score indicates a high degree of organisational coherence. Table 1 shows the detailed composition of the ORGA Score.

The second sub-score evaluates a pension fund's governance structure with respect to objectives setting and management incentive design. Our Management Objectives Score (MANO) has a minimum value of 0 and a maximum value of 7, whereby a high score indicates a high degree of objectives and incentives setting. Table 2 shows the detailed composition of the MANO Score.

The third sub-score evaluates a pension fund's governance structure with respect to its target setting and investment strategy definition process. The TSIS Score can assume values between 0 and 10. A high score indicates a highly structured approach regarding target setting and investment strategy design. Table 3 shows the detailed composition of the Target Setting and Investment Strategy Score. 
Table 1: Composition of the ORGA Score

\begin{tabular}{llc}
\hline Best Practice & Assessment Criteria & Score \\
\hline $\begin{array}{l}\text { Clarity of responsibilities and } \\
\text { separation of power }\end{array}$ & $\begin{array}{l}\text { Organisational regulations } \\
\text { Clear separation of executive and monitoring functions }\end{array}$ & 1 \\
& Specialisation of board of trustees in sub-committees & 1 \\
\hline $\begin{array}{l}\text { Effectiveness and efficiency of } \\
\text { management decision-making }\end{array}$ & $\begin{array}{l}\text { Full-time chief executive officer (CEO) } \\
\text { (depending on fund size) }\end{array}$ & 1 \\
Reasonable board composition & No excessive number of trustees & 1 \\
& No excessive number of investment committee members & 1 \\
& Mandatory retirement age & 1 \\
\hline Adequate internal qualification & No ex-officio members & 1 \\
and expertise & Comprehensive education concept & 1 \\
\hline Total ORGA Score & External specialists part of governing bodies & 1 \\
\hline
\end{tabular}

Notes: The Swiss Pension Fund Governance Score is divided into 6 sub-scores. The Organisation Score (ORGA) evaluates a pension fund's organisational form and coherence. It ranges from 0 to 10 whereby a high score indicates a high degree of organisational coherence and sound responsibility allocation.

Table 2: Composition of the MANO Score

\begin{tabular}{llc}
\hline Best Practice & Assessment Criteria & Score \\
\hline Mission clarity & Own written mission statement & 1 \\
$\begin{array}{l}\text { Clear management objectives } \\
\text { and supportive compensation } \\
\text { structures }\end{array}$ & $\begin{array}{l}\text { Management objectives defined for board of trustees } \\
\text { Performance-linked financial compensation of board } \\
\text { members } \\
\text { Individual management objectives defined for CEO } \\
\text { Performance-linked financial compensation of CEO }\end{array}$ & 1 \\
$\begin{array}{l}\text { Ongoing performance } \\
\text { monitoring of executives }\end{array}$ & Regular performance evaluation of CEO & 1 \\
$\begin{array}{l}\text { Awareness of governance } \\
\text { and internal compliance issues }\end{array}$ & Own written code of conduct & 1 \\
\hline Total MANO Score & & 1 \\
\hline
\end{tabular}

Notes: The Swiss Pension Fund Governance Score is divided into 6 sub-scores. The Management Objectives Score (MANO) evaluates a pension fund's governance structure in terms of objective definition. It ranges from 0 to 7 whereby a higher score indicates a higher degree of management objectives and incentives setting. 
Table 3: Composition of the TSIS Score

\begin{tabular}{llc}
\hline Best Practice & Assessment Criteria & Score \\
\hline Clear targets of financing & $\begin{array}{l}\text { Estimate of minimum required yield contains all } \\
\text { essential factors } \\
\text { Annual review of minimum required yield }\end{array}$ & 1 \\
\hline $\begin{array}{l}\text { Systematic investment strategy } \\
\text { planning }\end{array}$ & $\begin{array}{l}\text { Realistic estimate of the strategic asset allocation's } \\
\text { expected return } \\
\text { Realistic estimate of the strategic asset allocation's } \\
\text { expected volatility } \\
\text { Expected return of strategic asset allocation regularly } \\
\text { reviewed against minimum required yield } \\
\text { Expected return of strategic asset allocation } \geq \text { minimum } \\
\text { required yield } \\
\text { Independent external experts participate in investment } \\
\text { strategy meetings } \\
\text { Pension fund pursues active tactical asset allocation } \\
\text { Regular comparisons of effective to strategic asset } \\
\text { allocation } \\
\text { Regular investment strategy review }\end{array}$ & 1 \\
\hline Total TSIS Score & 1 \\
\hline
\end{tabular}

Notes: The Swiss Pension Fund Governance Score is divided into 6 sub-scores. The Target Setting and Investment Strategy Score (TSIS) evaluates a pension fund's quality in terms of target setting and investment strategy design. It ranges from 0 to 10 whereby a higher score indicates a higher quality in terms of target setting and systematic investment strategy definition.

The fourth sub-score evaluates a pension fund's governance structure with respect to its asset management processes. The Investment Process Score (INVP) can assume values between 0 and 10. A high score indicates a highly structured investment management process. Table 4 shows the detailed composition of the INVP Score.

The fifth sub-score evaluates a pension fund's risk management framework. A pension fund can obtain a minimum of 0 points and a maximum of 15 points in this category. A high score indicates a comprehensive risk management design. Table 5 shows the detailed composition of the RIMA Score.

The sixth and final sub-score evaluates a pension fund's governance with respect to its performance monitoring process and degree of managerial transparency. The Monitoring and Transparency Score (MOTR) can assume values between 0 and 8. A high score indicates a high monitoring quality and a high degree of transparency. Table 6 shows the detailed composition of the MOTR Score. 
Table 4: Composition of the INVP Score

\begin{tabular}{llc}
\hline Best Practice & Assessment Criteria & Score \\
\hline Systematic investment process & $\begin{array}{l}\text { Annual review of investment regulations } \\
\text { Detailed investment analysis for each asset class } \\
\text { Dedicated chief investment officer }\end{array}$ & 1 \\
Objectivity and transparency & $\begin{array}{l}\text { Catalogue of criteria for the selection and dismissal } \\
\text { of external asset managers } \\
\text { in employing external asset } \\
\text { managers }\end{array}$ & $\begin{array}{l}\text { External asset manager selection supported } \\
\text { by investment consultant } \\
\text { External asset manager mandates assigned based } \\
\text { on competitive tendering procedure } \\
\text { Regular revisions of external asset management costs }\end{array}$ \\
$\begin{array}{l}\text { External asset managers do not participate in investment } \\
\text { strategy meetings }\end{array}$ & 1 \\
$\begin{array}{l}\text { Investments with employer }<5 \% \\
\text { Ongoing asset-liability management } \\
\text { risks }\end{array}$ & 1 \\
\hline Total INVP Score & & 1 \\
\hline
\end{tabular}

Notes: The Swiss Pension Fund Governance Score is divided into 6 sub-scores. The Investment Process Score (INVP) evaluates a pension fund's governance structure in terms of its asset management processes. It ranges from 0 to 10 whereby a higher score indicates a higher investment process quality.

Table 5: Composition of the RIMA Score

\begin{tabular}{llc}
\hline Best Practice & Assessment Criteria & Score \\
\hline Clear understanding of risk & Regular assessment of own risk-bearing capacity & 1 \\
factors & Clearly defined risk budget & 1 \\
Comprehensive risk & Investment and market risks & 1 \\
management framework & Default and counterparty risks & 1 \\
& Financing and liquidity risks & 1 \\
& Solvency risk of the plan sponsor & 1 \\
& Actuarial risks & 1 \\
& Operational risks & 1 \\
& Regulatory risks & 1 \\
Ongoing risk monitoring & Regular quantitative assessment of total portfolio risk & 1 \\
& Regular quantitative assessment of portfolio risk per asset & 1
\end{tabular}




\begin{tabular}{llc}
\hline Best Practice & Assessment Criteria & Score \\
\hline Effective risk steering tools & $\begin{array}{l}\text { Risk management framework includes stress tests } \\
\text { Strategic emergency plan for disaster risks } \\
\text { Pre-defined guidelines for violations of tactical } \\
\text { fluctuation margins } \\
\text { Clear guidelines concerning the management } \\
\text { of foreign exchange risks }\end{array}$ & 1 \\
Total RIMA Score & & 1 \\
\hline
\end{tabular}

Notes: The Swiss Pension Fund Governance Score is divided into 6 sub-scores. The Risk Management Score (RIMA) evaluates a pension fund's risk management quality. It ranges from 0 to 15 whereby a high score indicates a comprehensive risk management design.

Table 6: Composition of the MOTR Score

\begin{tabular}{|c|c|c|}
\hline Best Practice & Assessment Criteria & Score \\
\hline $\begin{array}{l}\text { Objective investment } \\
\text { performance assessment }\end{array}$ & $\begin{array}{l}\text { Independent investment controller } \\
\text { Quantitative assessment of total investment performance } \\
\text { Quantitative assessment of investment performance per } \\
\text { asset management mandate }\end{array}$ & $\begin{array}{l}1 \\
1 \\
1\end{array}$ \\
\hline $\begin{array}{l}\text { Benchmarking with } \\
\text { industry peers }\end{array}$ & $\begin{array}{l}\text { Peer group benchmarking in terms of: } \\
\text { - Administration costs } \\
\text { - Asset management costs } \\
\text { - Investment performance } \\
\text { - Risk structure }\end{array}$ & $\begin{array}{l}0.5 \\
0.5 \\
0.5 \\
0.5\end{array}$ \\
\hline $\begin{array}{l}\text { Transparent information } \\
\text { disclosure }\end{array}$ & $\begin{array}{l}\text { All mandates of board members disclosed in the annual } \\
\text { report } \\
\text { Information concept for plan members about } \\
\text { shareholder voting rights } \\
\text { Annual report available on the internet }\end{array}$ & $\begin{array}{l}1 \\
1 \\
1\end{array}$ \\
\hline Total MOTR Score & & 8 \\
\hline
\end{tabular}

Notes: The Swiss Pension Fund Governance Score is divided into 6 sub-scores. The Monitoring and Transparency Score (MOTR) evaluates a pension fund's governance structure in terms of its monitoring process and its degree of managerial transparency. It ranges from 0 to 8 whereby a higher score indicates a higher monitoring quality and transparency degree. 


\section{Pension Fund Performance Measures}

Measuring the performance of pension portfolios is more complicated than of other collective investment vehicles. First, certain metrics are not suitable for pension plans, particularly when a pension fund manager outsources all or part of the portfolio allocation to external asset managers. Jensen's alpha ${ }^{1}$ is such an example. Second, even if alpha was used as performance measure, multifactor models to estimate alpha would be very difficult to employ due to the vast heterogeneity of the funds' asset allocations and the multitude of their risk factors. Moreover, we do not have a performance data time series for Swiss pension funds with which an alpha could be reasonably estimated. Therefore, in order to obtain a comprehensive understanding of pension fund performance, we draw on four different quantitative measures. Those are explained below:

To obtain a first overview of the plan performance on a non-risk-adjusted basis, we compute geometric mean returns in excess of the risk-free rate net of costs over the years 2010-2012 (ExcessReturn). In the following, this 3-year time period is referred to as the evaluation period. The risk-free rate is proxied by the average yield of 10-year Swiss confederation bonds.

To measure the value added by active asset management, we compare a pension fund's return net of portfolio management fees $\left(R_{P F}\right)$ against the return of a passively implemented benchmark strategy $\left(R_{P B}\right)$. A positive deviation from the benchmark indicates superior portfolio management, whereas a negative deviation indicates an underperformance relative to the passive strategy. The benchmark that we use for this analysis is based on standard market indices proxying major asset classes and the relative weights of the effective asset allocations as reported by the pension funds in our sample as of the end of 2012. In order to compare a pension fund's return against the benchmark return, we compute an individual allocation benchmark for each fund in the sample by multiplying the asset allocation weights with the annual returns of each asset class index. The detailed breakdown of the benchmark indices for each asset class is shown in Appendix 1. Since the effective asset allocations of Swiss pension funds have not changed fundamentally over the last three years, we assume the weights to remain constant during the evaluation period ${ }^{2}$. To capture the total out- or underperformance of the $k^{\text {th }}$ fund in this period, we compute the mean of the annual deviations from the benchmark of the years 2010-2012 (TE_AllocationBenchmark).

1 For a detailed explanation of this performance measure, see Jensen (1968).

2 For a detailed breakdown of the aggregated asset allocation weights of all Swiss pension funds for the years 2004-2012 see Appendix 2. 
A positive average "tracking error" should indicate an added value by the pension fund manager.

$$
T E_{-} \text {AllocationBenchmark } k=\frac{\sum_{i=1}^{3}\left(R_{P F k, i}-R_{P B k, i}\right)}{3}
$$

An additional, yet similar performance measure that we employ is a pension fund's deviation to its policy benchmark. Individual policy benchmark data for each fund was collected with our proprietary questionnaire ${ }^{3}$. The tracking error is computed as the mean difference between a pension fund's net return $\left(R_{P F}\right)$ and the return of its individual policy benchmark index $\left(R_{I B}\right)$ in the evaluation period (TE_PolicyBenchmark).

$$
T E_{-} \text {PolicyBenchmark }_{k}=\frac{\sum_{i=1}^{3}\left(R_{P F k, i}-R_{I B k, i}\right)}{3}
$$

Lastly, to capture pension fund performance on a risk-adjusted basis, we compute the pension funds' Sharpe ratios (Sharpe). Sharpe ratios are computed as the difference of the pension plans' geometric mean return of the years 2010-2012 $\left(\mu_{k}\right)$ and the risk-free rate as proxied by the geometric annual average yield of 10 -year Swiss confederation bonds $\left(R f_{k}\right)$ divided by the pension funds' annual volatility $\left(\sigma_{k}\right)$ for the 10 -year period. To eliminate distortionary effects of large outliers, pension portfolios with Sharpe ratios in excess of 1 are excluded from the analysis (3 funds excluded).

$$
\operatorname{Sharpe}_{k}=\frac{\mu_{k}-R f_{k}}{\sigma_{k}}
$$

3 Some few pension funds did report that they do not measure their performance against a benchmark. In those few cases, we used the passive benchmark instead. 


\section{Methodology}

In the following sections, we examine the relationship between governance and investment performance of Swiss occupational pension funds. To do this, we regress the different performance measures on our composite G-SCORE and its constituent sub-scores. Those metrics are estimated with the following model:

$$
\begin{aligned}
\text { PF_PM } & =\beta_{0}+\beta_{1} \text { SCORE }_{j}+\beta_{2} \text { Ln }(\text { Size })+\beta_{3} \text { Public }+\beta_{4} \text { DBPlan } \\
& +\beta_{5} \text { ClosedFund }+\beta_{6} \text { Autonomous }+\beta_{7} \text { RatioAP } \\
& +\beta_{8} \text { AMCosts }+\beta_{9} \text { AdminCosts }+\varepsilon
\end{aligned}
$$

whereby $P F_{-} P M$ is a vector of the different performance measures (as explained in section 3) and SCORE is a variable consisting of either our composite governance score $(j=1)$ or one of its constituent sub-scores $(j=2, \ldots, 6)$. Since we expect that pension fund size affects performance, we include the natural logarithm of the average pension assets of the period 2010-2012 into the equation $(\operatorname{Ln}($ Size)). To disentangle differences between public and private pension funds, we furthermore include the variable Public, which is a dummy variable assuming the value 1 for public pension funds and zero otherwise. Further control dummies are DBPlan and ClosedFund, which take on the value 1 for a defined benefit plan and a closed pension fund, respectively. Since we also want to investigate the relationship between the risk coverage on a pension fund's passive side and performance, we include the dummy variable Autonomous, which assumes the value 1 for autonomous pension funds and zero for all partly autonomous or fully insured funds. We furthermore expect that pension plans with more pensioners relative to active members have a different risk and return attitude that might affect asset allocation and hence indirectly performance. Therefore, we include the variable RatioAP into the equation, where Ratio $A P$ expresses the ratio of active participants to pensioners as averaged over the years 2010-2012. In their study, Ammann and ZiNGG (2010) find that asset management costs are negatively related to pension funds' investment performance as measured by their net value added variable. Since we expect that both administration and asset management costs reduce plan performance at the detriment of beneficiaries, we finally include the explanatory variables $A d \min C o s t s$ and $A M C o s t s$ into the regression. Both variables are measured as average costs in basis points of total assets over the 3-year investigation period. Appendix 3 shows a summary of the variables including their explanations. 
It should be noted at this point that our G-SCORE metric might potentially suffer from endogeneity - a well-known issue for governance variables or indices. For instance, it might be the case that well performing pension funds attract skilled managers to run the fund which, in turn, also has an effect on the governance structures. We cannot generally rule out such scenarios which might have an impact on the interpretations of our empirical results. It should furthermore be noted that our results allow no inferences about any causal relationship between governance and performance ${ }^{4}$. While it might be (more) likely that good pension fund governance drives superior investment performance, the causality might also run reversely in the sense that funds with good performance can, for whatever reasons, install better governance structures.

Finally, it should be noted that since all performance metrics are computed with realised 3-year data, our results might be somewhat "backward-predicting", however, as some governance variables might have changed over the 3 -year period ${ }^{5}$. The lack of publicly available data for Swiss pension funds as well as the trade-off between the scope of the survey and the response rate made it impossible to analyse a data panel. However, most of our governance variables are rather "sticky" in nature and unlikely to be altered on a frequent basis.

Motivated by the empirical findings of HARPER (2008), who finds that board composition of U.S. public pension funds is related to asset allocation decisions and thus indirectly to performance, we additionally examine the relationship between our governance variables and the effective asset allocation weights of the pension funds in our sample. Asset allocation data was obtained from each pension fund as of the end of 2012. To investigate this relationship, we make use of the following multivariate model:

$$
\begin{aligned}
A C_{n}= & \theta_{0}+\theta_{1} G-S C O R E_{j}+\theta_{2} \text { Size }+\theta_{3} \text { Public }+\theta_{4} \text { DBPlan } \\
& +\theta_{5} \text { ClosedFund }+\theta_{6} \text { Autonomous }+\theta_{7} \text { RatioAP }+\varepsilon
\end{aligned}
$$

whereby $A C_{n}$ is a vector of the different asset class weights, G-SCORE is our composite governance score and the remaining explanatory variables are the same as

4 Since we do not make any statements about the direction of causality, endogeneity issues are rather of little concern in our study.

5 For the Sharpe ratio analysis, we deliberately exclude the control variables RatioAP, AMCosts, and $A d \min C o s t s$ in order to avoid a time-dimension problem. 3 portfolios with Sharpe ratios in excess of 1 were excluded. 
employed in the performance analysis above ${ }^{6}$. Regressions are run stepwise on each weight in order to determine which factors are related to asset allocation decisions. Since the dependent variables (i.e., the allocation weights) are truncated, we employ a Tobit regression in which we specify the left-censoring limit to $0 \%$ and the right-sensoring limit to $100 \%$.

To account for the problem of multicollinearity, we compute correlations between the explanatory variables in both the performance and the asset allocation analysis. This statistical examination shows that governance is highly correlated to pension fund size. This has already been documented by AmmanN and ZINGG (2010), yet to a lesser extent. To avoid distortionary effects stemming from multicollinearity, the variable $\operatorname{Ln}($ Size) was orthogonalised before applied in the regression equation.

\section{Pension Fund Governance in Switzerland}

\subsection{Summary Statistics of the Sample}

The occupational pension system in Switzerland comprises a total number of 2,073 pension funds by the end of 2012 (Swiss Federal Statistical Office, 2014). Occupational insurance is mandatory. Every employee older than 17 years who receives an annual salary in excess of $21,060 \mathrm{CHF}$ is compulsorily required to join a registered pension scheme pursuant to the Federal Law on Occupational Old-age, Survivors' and Disability Pension Plans. Due to the limited availability of public data, we conduct a mail survey among 1,600 entities in order to evaluate their governance structures quantitatively. Of those, 139 returned completed questionnaires. This equals a response rate of around $9 \%$. Pension fund executives were asked about the governance criteria as described in detail in section 2 (and the appendix) of this paper and their realised investment performance net of costs for the years 2003-2012. The questionnaire furthermore contained questions about the institutional structure of the pension plan, its financial situation and risk coverage, its effective asset allocation as of the end of 2012 (including its benchmark performance), and its administration and asset management costs for the years 2010-2012. Table 7 provides the summary statistics of our sample as well as comparative statistics to the Swiss pension fund universe. Sample and universe data is reported as of the end of 2012.

6 Asset management costs (AMCosts) and administration costs (AdminCosts) have been deliberately excluded from this regression, as those variables are not deemed to be related to a pension fund's asset allocation mix. 
Table 7: Pension Fund Characteristics

\begin{tabular}{lcc}
\hline & Sample & Universe \\
\hline Number of occupational pension funds & 139 & 2,073 \\
thereof pension funds under public law & $22.3 \%$ & $4.4 \%$ \\
thereof pension funds under private law & $77.7 \%$ & $95.6 \%$ \\
Plan type & & \\
Defined contribution plan & $80.6 \%$ & $91.4 \%$ \\
Defined benefit plan & $15.1 \%$ & $5.3 \%$ \\
Dual plan & $4.3 \%$ & $3.3 \%$ \\
Plan model & & \\
Closed pension fund & $77.0 \%$ & $89.4 \%$ \\
Collective pension fund & $11.5 \%$ & $5.4 \%$ \\
Multi-employer plan & $11.5 \%$ & $5.2 \%$ \\
Risk coverage & & \\
Autonomous* & $71.2 \%$ & $40.4 \%$ \\
Partly autonomous & $24.5 \%$ & $51.1 \%$ \\
Full insurance & $4.3 \%$ & $8.5 \%$ \\
\hline
\end{tabular}

Notes: Number of pension plans, plan types, plan models, and risk coverage structures of our data sample compared to the entire Swiss pension fund universe. Sample and universe data is reported as of the end of 2012.

* pension funds with excess of loss- or stop-loss insurance are also considered autonomous

Table 7 shows that our sample is neither representative in terms of the structure nor in terms of the number of pension funds in Switzerland. It only covers around $7 \%$ of all registered Swiss occupational pension schemes as of the end of 2012. However, we consider our sample representative as far as total plan assets are concerned. It covers almost half of Switzerland's pension universe assets in all three years under scrutiny, as shown Table 8 . Table 8 furthermore shows that the sample is strongly heterogeneous in terms of the pension fund sizes. For the year 2012, the plan assets range from CHF 5.2 million (smallest fund) to CHF 34.9 billion (largest fund). The average plan assets per pension fund in 2012 amount to approximately CHF 2,061 million with a standard deviation of CHF 4,644 million. Hence, the sample average significantly exceeds the average pension fund size of CHF 324.6 million across all occupational pension schemes in Switzerland in 2012, implying that our sample is biased towards larger pension funds. The sample median for 2012 amounts to CHF 315 million. The sample is thus strongly influenced by a small number of very large pension funds. This is not surprising: More than $22 \%$ of pension funds that are included in our sample are set up under public law. Those funds are organised on either the cantonal or the 
Table 8: Pension Fund Assets and Actuarial Parameters

\begin{tabular}{lccc}
\hline & $\mathbf{2 0 1 0}$ & $\mathbf{2 0 1 1}$ & $\mathbf{2 0 1 2}$ \\
\hline Pension plan assets* & $\mathbf{2 6 2 , 8 5 4}$ & $\mathbf{2 6 5 , 1 9 9}$ & $\mathbf{2 8 6 , 4 9 5}$ \\
(in \% of Swiss universe) & $(42.3 \%)$ & $(42.4 \%)$ & $(42.6 \%)$ \\
Average assets per pension fund & $1,891.0$ & $1,907.9$ & $2,061.1$ \\
Median & 283.3 & 301.0 & 315.0 \\
SD & $4,305.6$ & $4,304.2$ & $4,643.6$ \\
Min & 3.0 & 3.9 & 5.2 \\
Max & $33,158.0$ & $32,984.0$ & $34,938.0$ \\
Pension plan coverage ratios & & & \\
Mean & $103.5 \%$ & $101.0 \%$ & $104.3 \%$ \\
Median & $104.4 \%$ & $101.6 \%$ & $106.4 \%$ \\
SD & $12.3 \%$ & $12.6 \%$ & $15.2 \%$ \\
Min & $56.0 \%$ & $53.2 \%$ & $26.1 \%$ \\
Max & $141.3 \%$ & $162.0 \%$ & $178.0 \%$ \\
\hline Average technical interest rate** & $3.6 \%$ & $3.5 \%$ & $3.3 \%$ \\
Ratio active participants to pensioners & 2.99 & 2.96 & 2.92 \\
\hline
\end{tabular}

Notes: Plan assets, coverage ratios, technical interest rates, and the ratio of active plan members to retirees of our sample funds for the years 2010-2012. The data is based on the 139 returned questionnaires.

* without assets from insurance contracts; in million CHF

** 2 pension funds did not report technical interest rates for the years 2010-2012

federal level. Since they insure a large number of public sector employees, they are naturally very large in terms of assets under management. By the end of 2012, Switzerland administered 91 public pension funds which held almost $30 \%$ of total universe plan assets (Swiss Federal Statistical Office, 2014). Of those, 31 are included in our sample. Hence, as compared to the Swiss pension fund universe, public pension funds are overrepresented in our data.

Our questionnaire also included questions about the risk coverage on the pension entities' liability side. As shown in Table 7 , more than $71 \%$ of sample funds bear old-age, death, and disability risks themselves. This is a typical characteristic for larger pension funds. As compared to the entire pension fund universe, autonomous pension plans are thus also overrepresented in the sample, whereas partly autonomous plans are underrepresented. Funds that fully insure their liability risks (including investment risks) account for only a very small sample fraction. Table 8 additionally summarises selected actuarial parameters for the years 2010-2012. It shows that the arithmetic mean of the coverage ratios in all three years is in excess of $100 \%$. In 2012 , only $19.4 \%$ of pension funds in our 
Table 9: Asset Management and Administration Costs

\begin{tabular}{lccc}
\hline & 2010 & 2011 & 2012 \\
\hline General administration costs* & 17.1 & 16.7 & 15.7 \\
Direct asset management costs* & 17.5 & 17.7 & 17.8 \\
Proportion of non-transparent investment vehicles** & N/A & N/A & 4.9 \\
TER of transparent collective investment vehicles** & 28.0 & 36.1 & 33.7 \\
\hline
\end{tabular}

Notes: Administration costs, asset management costs, proportions of non-transparent investment vehicles, and total expense ratios (TERs) of transparent collective investment vehicles in our sample for the years 2010 to 2012 .

* arithmetic mean of all reporting funds; figures stated in basis points of total assets.

** in per cent of total assets; pursuant Article 48a (3) BVV2; only 69 pension funds reported data for 2012.

*** average total expense ratio of cost-transparent collective investment vehicles included in the asset portfolio of the pension funds; figures are stated in basis points of cost-transparent assets; only 63 pension funds reported data for 2012. For 2011 and 2010, we only received data from 27 and 18 entities, respectively.

sample had funding ratios below $100 \%$. This implies that our sample is biased towards rather fully funded pension funds. Since the risk-bearing capacity of a pension plan is partly related to its funding level, the sample is therefore likely to include funds that are more inclined to invest in riskier assets. It is furthermore noteworthy that our sample includes a relatively large fraction of pensioners. The average ratio of active participants to pensioners for the years 2010-2012 amounts to around 3, whereas the same average amounts to approximately 5.1 for the Swiss universe (Swiss Federal Statistical Office, 2014). In 2012, the plans in our sample include almost half of Switzerland's recipients of occupational old-age and disability benefits. This might possibly have implications for the funds' aggregated asset allocation.

Since we aim to investigate the pension schemes' performance net of costs, we also asked pension fund executives about their internal costs structures. Table 9 depicts a detailed breakdown of the general administration costs, direct asset management costs, and indirect asset management costs of transparent collective investment vehicles for our sample funds for the years $2010-2012^{7}$.

7 Direct asset management costs are defined as expenses that are included in a pension fund's profit and loss account (e.g., costs for external asset management mandates) whereas indirect asset management costs are defined as expenses that are not directly included in a pension fund's income statement but related to collective investment vehicles (e.g., such as annual fund management fees, loads for mutual funds, etc.). 


\subsection{Results of the Survey}

To examine the current governance state of our sample pension funds, we create the Swiss Pension Fund Governance Score (G-SCORE). The G-SCORE metric is based on the responses of the 139 Swiss occupational pension funds that have completed our standardised questionnaire. The basis for the questionnaire are the assessment criteria as described in section 2 of this paper. Table 10 summarises the results of the 6 sub-scores and the overall composite score for the sample. It can assume values between 0 and 60 whereby a high score implies a sound and comprehensive internal governance structure. The maximum achievable points for each category are reported in parentheses. Table 11 depicts the summary statistics of the performance measures as computed in section 3 .

On average, pension plans obtained 32.4 points on the composite score. The mean as a percentage of the score maximum lies slightly above $50 \%$. Composite G-SCORE points range from 10.5 (lowest) to 49.5 (highest). Half of the pension funds obtained scores in excess of 33.6. No pension fund in our sample achieved the maximum score that can be possibly reached (60 points).

Governance structures were found to be relatively comprehensive in the areas of target setting and investment strategy definition, investment processes and risk management. In the areas of management objective design, monitoring effectiveness and transparency there is still room for improvement, however. Although clear management objectives are an essential component of good governance, only about $34 \%$ of pension funds in our sample reported to have an own written statement regarding their strategic goals (i.e., mission statement). Even more notably, only $22 \%$ reported to have defined management objectives for the board of trustees, whereas more than $72 \%$ of entities had defined management objectives for the $\mathrm{CEO}$ or senior pension fund executive(s). In opposition to the recommendations of Ambachtsheer, Capelle, and Scheibelhut (1998), compensation policies for both executive and supervisory committee members of Swiss occupational pension plans are not reasonably linked to performance. Only 3 pension funds reported that their CEOs' financial compensation is linked to individual objectives or the funds' investment performance. Almost two thirds of CEOs or senior executives receive fixed financial compensation without a variable component. For trustee boards, performance-linked compensation is effectively not existing in Switzerland. No single pension fund in our sample compensates its trustee board members based on the achievement of individual objectives or plan performance. The majority of trustees are solely reimbursed for their expenses or obtain a flat-fee expense allowance. About $14 \%$ of trustees do not receive financial compensation at all. 
Table 10: Summary Results of the Swiss Pension Fund Governance Score

\begin{tabular}{lcccccc}
\hline & Mean & Median & SD & Min & Max & MPSM* $^{*}$ \\
\hline ORGA Score (10) & 5.1 & 5.0 & 1.9 & 1.0 & 9.0 & $51.4 \%$ \\
MANO Score (7) & 2.9 & 3.0 & 1.7 & 0.0 & 6.5 & $41.0 \%$ \\
TSIS Score (10) & 6.5 & 6.5 & 1.5 & 1.5 & 9.5 & $64.8 \%$ \\
INVP Score (10) & 6.1 & 6.0 & 1.8 & 2.0 & 10.0 & $60.5 \%$ \\
RIMA Score (15) & 8.3 & 8.6 & 3.7 & 0.0 & 15.0 & $55.2 \%$ \\
MOTR Score (8) & 3.6 & 4.0 & 1.5 & 0.0 & 7.5 & $44.8 \%$ \\
\hline Composite G-SCORE (60) & 32.4 & 33.6 & 8.9 & 10.5 & 49.5 & $54.0 \%$ \\
\hline
\end{tabular}

Notes: The table shows the summary statistics for the 6 sub-scores and the overall composite score. Maximum achievable points for each category are shown in parentheses. The results are based on 139 observations.

* $\quad \mathrm{MPSM}=$ Mean as percentage of score maximum

Table 11: Descriptive Statistics of the Performance Measures

\begin{tabular}{lccccc}
\hline Performance Measure & Mean & Median & SD & Min & Max \\
\hline ExcessReturn & $2.1 \%$ & $2.0 \%$ & $0.9 \%$ & $-0.6 \%$ & $4.7 \%$ \\
TE_AllocationBenchmark & $-0.9 \%$ & $-0.9 \%$ & $1.0 \%$ & $-3.9 \%$ & $1.9 \%$ \\
TE_PolicyBenchmark & $-0.7 \%$ & $-0.5 \%$ & $1.1 \%$ & $-3.7 \%$ & $1.7 \%$ \\
Sharpe & 0.31 & 0.31 & 0.16 & -0.08 & 0.92 \\
\hline
\end{tabular}

Notes: The table shows the descriptive statistics for the four performance measures for the years 2010-2012.

Our survey furthermore reveals that risk management is an important issue on the agenda of Swiss pension plan managers. Only about $12 \%$ of funds in our sample reported to undertake no active risk management. Regular assessment of risk-bearing capacity is conducted by more than $90 \%$ of the plans. However, although most pension funds do make use of risk management practices, specific risk factors such as portfolio tail risks receive less attention. Only 16\% of funds reported to have a strategic emergency plan for disaster risks in place. While a number of European financial regulators require mandatory stress tests for occupational pension arrangements, only about one third of pension funds in our sample include internal stress tests in their risk management frameworks. 
Particularly larger pension funds with plan assets in excess of CHF 1 billion do not systematically conduct such analyses ${ }^{8}$.

We moreover find evidence for a lack of professional expertise among the governing bodies. More than $70 \%$ of funds in our sample reported to have trustee board members that are not elected because of their specialised knowledge regarding pension issues. Task-specific education programs for trustees are neither pervasive. Around $39 \%$ of sample funds have not established any education or training concept for trustees or executives. This is an alarming result given the extensive fiduciary responsibility that board members have to the pension plans' beneficiaries. Although recommended in the literature, mandatory retirement provisions for board members and board term limits are not common in Switzerland. Only $24 \%$ of pension funds in our sample make use of maximum age thresholds while around $18 \%$ have established term limits.

Some minor issues were also identified in the area of monitoring and transparency. For instance, in contrast to corporate boards in Switzerland, trustee boards are not legally required to disclose their members' additional mandates in the plans' annual report. Our survey reveals that only very few (8.6\%) pension entities in our sample disclose those mandates on a voluntary basis. Transparency is moreover lacking in terms of informing plan stakeholders about internal policies to exercise shareholder voting rights. Although new legal regulations require the mandatory exercise of voting rights attached to portfolio stocks, less than one third of funds in the sample have established an explicit information concept for their active members and pensioners.

Overall, we do not find any systematic governance weaknesses in the Swiss occupational pension fund system. It is possible, however, that this may be driven by a self-selection bias in the sense that pension funds with inferior governance structures may not have responded to our questionnaire request. Since our sample is moreover biased towards larger funds, we might potentially overestimate the governance quality of the entire Swiss pension plan universe. Those limitations might also have implications for the interpretations of the empirical results as described below.

8 Of the 44 large funds in our sample (as measured by plan assets at the end of 2012), only 19 reported to include stress testing techniques in their risk management frameworks. 


\section{Empirical Findings}

Table 12 shows the results of the initial analysis of the sample funds' governance categories. We split our sample into G-SCORE quartiles and sort them from highest (1) to lowest (4). Table 12 shows that the arithmetic average of each respective performance metric within each goverance quartile decreases monotonically for all of the analysed metrics. For both variables ExcessReturn and $T E_{-}$ AllocationBenchmark, the average within the highest governance quartile exceeds the average within the lowest quartile by approximately $1 \%$. Pension funds within the highest G-SCORE quartile furthermore underperform, on average, their individual policy benchmarks (i.e., TE_PolicyBenchmark) by around 75 basis points less than their lowest quartile counterparts. The Sharpe ratio difference between quartile 1 and 4 is also positive, as shown in the table.

Table 12: Quartile Analysis

\begin{tabular}{l|cccc|c}
\hline & \multicolumn{5}{|c|}{ G-SCORE Quartile } \\
Performance Metric & Highest & & & Lowest & \\
& 1 & 2 & 3 & 4 & $\Delta$ High-Low \\
\hline ExcessReturn & $2.65 \%$ & $2.21 \%$ & $1.81 \%$ & $1.62 \%$ & $+1.02 \% \%^{* * *}$ \\
TE_AllocationBenchmark & $-0.36 \%$ & $-0.83 \%$ & $-1.20 \%$ & $-1.33 \%$ & $+0.97 \%^{* * *}$ \\
TE_PolicyBenchmark & $-0.31 \%$ & $-0.60 \%$ & $-0.88 \%$ & $-1.06 \%$ & $+0.75 \%^{* *}$ \\
Sharpe & 0.376 & 0.299 & 0.295 & 0.271 & $+0.105^{* *}$ \\
\hline
\end{tabular}

Notes: The table shows the arithmetic average of each of the four analysed performance measures for each respective G-SCORE quartile category. $\Delta$ High-Low shows the difference between the top quartile average and the bottom quartile average of each employed metric. ExcessReturn is the average excess return of the years 2010-2012. TE_AllocationBenchmark is the average deviation from the passive benchmark strategy for the years 2010-2012. TE_PolicyBenchmark is the average deviation from the pension funds own policy benchmark for the years 2010-2012. Sharpe is the pension funds' Sharpe ratio, as defined in section 3 of this paper.

*** $1 \%$ significance; ${ }^{* *} 5 \%$ significance; ${ }^{*} 10 \%$ significance.

In order to control for other factors that might be related to superior net investment performance, we conduct the multivariate regressions, as defined in section 4. Table 13 shows the empirical results of the relationship between governance and the sample funds' excess performance during the evaluation period. Our analysis reveals that governance is positively related to average excess returns. Governance structure, as measured by our composite G-SCORE, affects mean 
Table 13: Governance and Excess Returns

Dependent Variable $=$ ExcessReturn

\begin{tabular}{|c|c|c|c|c|c|c|c|}
\hline & 1 & 2 & 3 & 4 & 5 & 6 & 7 \\
\hline G-SCORE & $\begin{array}{l}2.8^{* *} \\
(2.40)\end{array}$ & & & & & & \\
\hline ORGA Score & & $\begin{array}{l}0.6 \\
(0.12)\end{array}$ & & & & & \\
\hline MANO Score & & & $\begin{array}{c}9.1^{*} \\
(1.78)\end{array}$ & & & & \\
\hline TSIS Score & & & & $\begin{array}{c}14.4^{* * *} \\
(2.61)\end{array}$ & & & \\
\hline INVP Score & & & & & $\begin{array}{l}1.3 \\
(0.26)\end{array}$ & & \\
\hline RIMA Score & & & & & & $\begin{array}{l}5.5^{* *} \\
(2.26)\end{array}$ & \\
\hline MOTR Score & & & & & & & $\begin{array}{l}8.7 \\
(1.38)\end{array}$ \\
\hline Constant & $\begin{array}{c}139.9^{* * *} \\
(2.99)\end{array}$ & $\begin{array}{c}226.7^{* * *} \\
(5.53)\end{array}$ & $\begin{array}{c}198.2^{* * *} \\
(5.93)\end{array}$ & $\begin{array}{c}145.6^{* * *} \\
(3.42)\end{array}$ & $\begin{array}{c}221.8^{* * *} \\
(5.23)\end{array}$ & $\begin{array}{c}189.1^{* * *} \\
(5.67)\end{array}$ & $\begin{array}{c}199.5^{* * *} \\
(5.54)\end{array}$ \\
\hline $\operatorname{Ln}($ Size $)$ & $\begin{array}{c}22.5^{*} \\
(1.70)\end{array}$ & $\begin{array}{c}42.0^{* * * *} \\
(3.29)\end{array}$ & $\begin{array}{c}33.0^{* * * *} \\
(2.84)\end{array}$ & $\begin{array}{c}38.4^{* * * *} \\
(3.75)\end{array}$ & $\begin{array}{c}41.6^{* * * *} \\
(3.65)\end{array}$ & $\begin{array}{c}28.0^{* *} \\
(2.31)\end{array}$ & $\begin{array}{c}199.5^{* * *} \\
(5.54)\end{array}$ \\
\hline Public & $\begin{array}{l}-8.9 \\
(-0.45)\end{array}$ & $\begin{array}{r}-14.7 \\
(-0.70)\end{array}$ & $\begin{array}{r}-14.8 \\
(-0.74)\end{array}$ & $\begin{array}{r}-10.6 \\
(-0.53)\end{array}$ & $\begin{array}{r}-14.8 \\
(-0.73)\end{array}$ & $\begin{array}{r}-13.4 \\
(-0.68)\end{array}$ & $\begin{array}{r}-14.4 \\
(-0.72)\end{array}$ \\
\hline DBPlan & $\begin{array}{r}-11.9 \\
(-0.60)\end{array}$ & $\begin{array}{r}-13.8 \\
(-0.68)\end{array}$ & $\begin{array}{r}-14.8 \\
(-0.74)\end{array}$ & $\begin{array}{l}0.58 \\
(0.03)\end{array}$ & $\begin{array}{r}-13.5 \\
(-0.67)\end{array}$ & $\begin{array}{r}-15.1 \\
(-0.77)\end{array}$ & $\begin{array}{r}-12.7 \\
(-0.64)\end{array}$ \\
\hline ClosedFund & $\begin{array}{l}-5.8 \\
(-0.31)\end{array}$ & $\begin{array}{l}-8.1 \\
(-0.42)\end{array}$ & $\begin{array}{l}-8.7 \\
(-0.46)\end{array}$ & $\begin{array}{l}-0.3 \\
(-0.02)\end{array}$ & $\begin{array}{l}-7.4 \\
(-0.38)\end{array}$ & $\begin{array}{r}-13.0 \\
(-0.68)\end{array}$ & $\begin{array}{l}-3.7 \\
(-0.19)\end{array}$ \\
\hline Autonomous & $\begin{array}{l}-8.7 \\
(-0.42)\end{array}$ & $\begin{array}{r}-10.7 \\
(-0.51)\end{array}$ & $\begin{array}{l}-4.0 \\
(-0.19)\end{array}$ & $\begin{array}{l}-28.1 \\
(-1.31)\end{array}$ & $\begin{array}{r}-10.9 \\
(-0.52)\end{array}$ & $\begin{array}{l}-3.8 \\
(-0.18)\end{array}$ & $\begin{array}{r}-12.7 \\
(-0.61)\end{array}$ \\
\hline RatioAP & $\begin{array}{r}0.24 \\
(1.07)\end{array}$ & $\begin{array}{l}0.28 \\
(1.27)\end{array}$ & $\begin{array}{c}0.27 \\
(1.21)\end{array}$ & $\begin{array}{l}0.23 \\
(1.02)\end{array}$ & $\begin{array}{c}0.27 \\
(1.20)\end{array}$ & $\begin{array}{c}0.27 \\
(1.24)\end{array}$ & $\begin{array}{r}0.30 \\
(1.36)\end{array}$ \\
\hline AMCosts & $\begin{array}{l}-0.34 \\
(-0.49)\end{array}$ & $\begin{array}{l}-0.15 \\
(-0.21)\end{array}$ & $\begin{array}{l}-0.06 \\
(-0.09)\end{array}$ & $\begin{array}{l}-0.25 \\
(-0.37)\end{array}$ & $\begin{array}{l}-0.14 \\
(-0.20)\end{array}$ & $\begin{array}{l}-0.38 \\
(-0.54)\end{array}$ & $\begin{array}{l}-0.30 \\
(-0.43)\end{array}$ \\
\hline AdminCosts & $\begin{array}{l}-0.30 \\
(-0.45)\end{array}$ & $\begin{array}{l}-0.19 \\
(-0.29)\end{array}$ & $\begin{array}{l}-0.18 \\
(-0.26)\end{array}$ & $\begin{array}{l}-0.42 \\
(-0.63)\end{array}$ & $\begin{array}{l}-0.21 \\
(-0.30)\end{array}$ & $\begin{array}{l}-0.32 \\
(-0.47)\end{array}$ & $\begin{array}{l}-0.12 \\
(-0.32)\end{array}$ \\
\hline $\mathrm{R}^{2}$ adj. & 0.165 & 0.128 & 0.149 & 0.172 & 0.128 & 0.161 & 0.140 \\
\hline
\end{tabular}

Notes: The table shows the results of the regressions (1-7) of our model on the 3-year average excess return of the sample pension funds for the period 2010-2012 (ExcessReturn). Adjusted $\mathrm{R}^{2} s$ of the models are shown in the bottom line of the table. T-statistics are shown in parentheses. Coefficient estimates are reported in basis points. The results are based on 139 observations.

${ }^{* * *} 1 \%$ significance; ${ }^{* *} 5 \%$ significance; ${ }^{*} 10 \%$ significance. 
excess returns by around 3 basis points. Put differently, a one-standard deviation increase in the composite score $(\sigma=8.9)$ is associated with an increase in excess performance of roughly 25 basis points. The economic magnitude of our results are therefore clearly significant. Particularly target setting and investment strategy definition as well as risk management design is strongly positively related to the average investment performance in excess of the risk-free rate. This is not surprising, as the TSIS Score includes essential governance factors that are directly related to a pension fund's portfolio strategy. The analysis of the individual TSIS Score components shows that particularly independent external experts that participate in investment strategy meetings have a substantial positive relation to performance. Pension plans in our sample that draw on such outside advisers have a higher mean excess return by approximately 51 basis points.

We furthermore find evidence that pension fund size is strongly positively related to average excess performance. Our analysis shows that larger pension funds have been able to achieve, on average, higher excess returns than smaller funds during the evaluation period. This result can be explained by the fact that larger pension schemes are likely to have more institutionalised internal governance processes in place. This has also been documented by Yermo and STEWART (2008), who claim that small funds are less likely to achieve comparable levels of performance than large funds, even gross of fees, due to weaker governance structures and inconsistent internal processes. It might also explain why governance is strongly correlated to plan size in our sample. By contrast, legal form, pension fund type, pension fund model, risk coverage, and administration and asset management costs do not affect the mean excess performance measurably. Surprisingly, autonomous pension funds, which are usually large in size, do not have a significantly higher average investment performance. Neither do we find any statistically robust evidence for an effect of direct asset management costs, which should theoretically reduce the net performance.

The relationship between governance and the value added by a pension fund's asset manager is shown in Table 14 and Table 15. Our results also point to a positive relationship between governance structure and the 3-year arithmetic mean difference between net fund return and the return of the passive benchmark strategy. The effect has a magnitude of approximately 2.8 basis points per G-SCORE point. This result is again primarily driven by the constituent subscores TSIS and RIMA.

In addition to governance, our data shows that the ratio of active plan members to plan pensioners is positively related to outperformance as measured by the variable TE_AllocationBenchmark. Pension funds with more active members underperform the passive benchmark to a lesser extent. This might be explained 
Table 14: Governance and Outperformance of the Passive Benchmark Dependent Variable $=T E \_$AllocationBenchmark

\begin{tabular}{|c|c|c|c|c|c|c|c|}
\hline & 1 & 2 & 3 & 4 & 5 & 6 & 7 \\
\hline G-SCORE & $\begin{array}{l}2.8^{* *} \\
(2.28)\end{array}$ & & & & & & \\
\hline ORGA Score & & $\begin{array}{l}-0.7 \\
(-0.12)\end{array}$ & & & & & \\
\hline MANO Score & & & $\begin{array}{l}9.4^{*} \\
(1.73)\end{array}$ & & & & \\
\hline TSIS Score & & & & $\begin{array}{c}10.3^{*} \\
(1.74)\end{array}$ & & & \\
\hline INVP Score & & & & & $\begin{array}{l}1.7 \\
(0.33)\end{array}$ & & \\
\hline RIMA Score & & & & & & $\begin{array}{l}6.5^{* *} \\
(2.53)\end{array}$ & \\
\hline MOTR Score & & & & & & & $\begin{array}{l}8.8 \\
(1.31)\end{array}$ \\
\hline Constant & $\begin{array}{c}-154.4^{* * *} \\
(-3.10)\end{array}$ & $\begin{array}{c}-59.5 \\
(-1.37)\end{array}$ & $\begin{array}{c}-96.1^{* * *} \\
(-2.71)\end{array}$ & $\begin{array}{c}-123.8^{* * *} \\
(-2.70)\end{array}$ & $\begin{array}{r}-74.2^{*} \\
(-1.65)\end{array}$ & $\begin{array}{c}-111.6^{* * *} \\
(-3.17)\end{array}$ & $\begin{array}{c}-94.0^{* * *} \\
(-2.46)\end{array}$ \\
\hline $\operatorname{Ln}($ Size $)$ & $\begin{array}{l}20.0 \\
(1.42)\end{array}$ & $\begin{array}{l}41.5^{* * *} \\
(3.06)\end{array}$ & $\begin{array}{c}30.4^{* *} \\
(2.46)\end{array}$ & $\begin{array}{c}37.4^{* * *} \\
(3.39)\end{array}$ & $\begin{array}{c}38.9^{* * *} \\
(3.22)\end{array}$ & $\begin{array}{c}23.0^{*} \\
(1.80)\end{array}$ & $\begin{array}{l}33.2^{* * *} \\
(2.70)\end{array}$ \\
\hline Public & $\begin{array}{l}-20.6 \\
(-0.97)\end{array}$ & $\begin{array}{l}-27.8 \\
(-1.25)\end{array}$ & $\begin{array}{l}-26.6 \\
(-1.26)\end{array}$ & $\begin{array}{l}-23.7 \\
(-1.11)\end{array}$ & $\begin{array}{l}-26.4 \\
(-1.22)\end{array}$ & $\begin{array}{l}-24.9 \\
(-1.19)\end{array}$ & $\begin{array}{l}-26.3 \\
(-1.23)\end{array}$ \\
\hline DBPlan & $\begin{array}{l}-6.6 \\
(-0.33)\end{array}$ & $\begin{array}{l}-8.3 \\
(-0.39)\end{array}$ & $\begin{array}{l}-9.6 \\
(-0.45)\end{array}$ & $\begin{array}{l}1.8 \\
(0.08)\end{array}$ & $\begin{array}{l}-8.2 \\
(-0.38)\end{array}$ & $\begin{array}{l}-10.2 \\
(-0.49)\end{array}$ & $\begin{array}{l}-7.5 \\
(-0.35)\end{array}$ \\
\hline ClosedFund & $\begin{array}{l}-30.5 \\
(-1.52)\end{array}$ & $\begin{array}{l}-32.9 \\
(-1.61)\end{array}$ & $\begin{array}{l}-33.4 \\
(-1.65)\end{array}$ & $\begin{array}{l}-27.2 \\
(-1.33)\end{array}$ & $\begin{array}{l}-31.8 \\
(-1.54)\end{array}$ & $\begin{array}{r}-38.5^{*} \\
(-1.92)\end{array}$ & $\begin{array}{l}-28.3 \\
(-1.38)\end{array}$ \\
\hline Autonomous & $\begin{array}{l}-14.8 \\
(-0.68)\end{array}$ & $\begin{array}{c}-17.2 \\
(-0.77)\end{array}$ & $\begin{array}{l}-10.0 \\
(-0.45)\end{array}$ & $\begin{array}{l}-29.5 \\
(-1.28)\end{array}$ & $\begin{array}{c}-17.1 \\
(-0.77)\end{array}$ & $\begin{array}{l}-8.7 \\
(-0.40)\end{array}$ & $\begin{array}{c}-18.9 \\
(-0.85)\end{array}$ \\
\hline RatioAP & $\begin{array}{l}0.61^{* *} \\
(2.59)\end{array}$ & $\begin{array}{l}0.66^{* * *} \\
(2.77)\end{array}$ & $\begin{array}{l}0.64^{* * *} \\
(2.72)\end{array}$ & $\begin{array}{l}0.62^{* * *} \\
(2.60)\end{array}$ & $\begin{array}{l}0.64^{* * *} \\
(2.65)\end{array}$ & $\begin{array}{l}0.64^{* * *} \\
(2.77)\end{array}$ & $\begin{array}{l}0.68^{* * *} \\
(2.85)\end{array}$ \\
\hline AMCosts & $\begin{array}{l}-0.27 \\
(-0.37)\end{array}$ & $\begin{array}{l}-0.07 \\
(-0.09)\end{array}$ & $\begin{array}{c}0.01 \\
(0.01)\end{array}$ & $\begin{array}{l}-0.15 \\
(-0.21)\end{array}$ & $\begin{array}{l}-0.07 \\
(-0.09)\end{array}$ & $\begin{array}{l}-0.35 \\
(-0.48)\end{array}$ & $\begin{array}{l}-0.24 \\
(-0.32)\end{array}$ \\
\hline AdminCosts & $\begin{array}{l}-0.56 \\
(-0.79)\end{array}$ & $\begin{array}{l}-0.46 \\
(-0.64)\end{array}$ & $\begin{array}{l}-0.44 \\
(-0.61)\end{array}$ & $\begin{array}{l}-0.62 \\
(-0.86)\end{array}$ & $\begin{array}{l}-0.47 \\
(-0.65)\end{array}$ & $\begin{array}{l}-0.60 \\
(-0.85)\end{array}$ & $\begin{array}{l}-0.47 \\
(-0.66)\end{array}$ \\
\hline $\mathrm{R}^{2}$ adj. & 0.177 & 0.144 & 0.163 & 0.164 & 0.144 & 0.184 & 0.155 \\
\hline
\end{tabular}

Notes: The table shows the results of the regressions (1-7) of our model on the 3-year arithmetic mean of the difference between the net fund return and the return of the passively implemented strategy for the period 2010-2012 (TE_AllocationBenchmark). Adjusted $\mathrm{R}^{2} \mathrm{~s}$ of the models are shown in the bottom line of the table. T-statistics are shown in parentheses. Coefficient estimates are reported in basis points. The results are based on 139 observations.

*** $1 \%$ significance; ${ }^{* *} 5 \%$ significance; ${ }^{*} 10 \%$ significance. 
by the different risk attitude and asset allocation of pension funds that have more active members relative to pensioners. Moreover, we find that larger pension funds do not only have higher average excess performance, but also underperform the passive investment strategy to a lesser extent. In order to test the results of the TE_AllocationBenchmark variable for robustness, we furthermore measure outperformance with the mean deviation of a plan's investment performance to its own policy benchmark as reported in our questionnaire. Using this performance metric, we find similar results. As shown in Table 15, target setting and investment strategy definition is primarily related to mean outperformance of a fund's policy benchmark. The effect for the TSIS Score is as large as around 21.5 basis points. Interestingly, in the analysis of the individual TSIS Score components on TE_PolicyBenchmark, the size factor disappears entirely for this variable. The positive mean deviation from the individual policy benchmark can thus not be explained by the average pension assets under management. This might be due to the fact that the funds' customised policy benchmarks are often chosen inconsistently with their effective asset allocations. The relatively low adjusted $\mathrm{R}^{2} \mathrm{~s}$ for this particular model and the large negative constant term additionally point to this.

In contrast to our expectations, organisational setup and investment process design is neither related to mean excess returns nor to benchmark outperformance. We find no empirical evidence that board governance factors such as separation of executive and supervisory functions, trustee board size, or the existence of an education concept are related to superior investment performance. Even if we alter the above-defined size thresholds for the board of trustees or the investment committees, we find no statistically significant results. Neither do we find any effect for investment process factors such as asset manager selection procedures or the existence of a chief investment officer. Those factors do not explain excess returns or positive benchmark deviations for the funds in our sample. This result is somewhat counterintuitive, as particularly the components of the INVP Score are directly associated with a pension fund's asset management processes. To validate these findings, we conduct an examination of the individual INVP Score components for those funds that reported to have external asset managers on board'. The analysis validates our initial results. We do not find any empirical evidence that external asset manager selection procedures are related to superior performance. While structured procedures are nonetheless

9 Of the 139 respondents, 14 stated that they had not assigned external mandates by the end of 2012. 
Table 15: Governance and Outperformance of the Policy Benchmark Dependent Variable $=T E_{-}$PolicyBenchmark

\begin{tabular}{|c|c|c|c|c|c|c|c|}
\hline & 1 & 2 & 3 & 4 & 5 & 6 & 7 \\
\hline G-SCORE & $\begin{array}{l}3.0^{* *} \\
(2.09)\end{array}$ & & & & & & \\
\hline ORGA Score & & $\begin{array}{l}-2.1 \\
(-0.32)\end{array}$ & & & & & \\
\hline MANO Score & & & $\begin{array}{l}5.0 \\
(0.79)\end{array}$ & & & & \\
\hline TSIS Score & & & & $\begin{array}{c}21.5^{* * *} \\
(3.22)\end{array}$ & & & \\
\hline INVP Score & & & & & $\begin{array}{l}6.8 \\
(1.14)\end{array}$ & & \\
\hline RIMA Score & & & & & & $\begin{array}{l}4.6 \\
(1.52)\end{array}$ & \\
\hline MOTR Score & & & & & & & $\begin{array}{l}12.0 \\
(1.56)\end{array}$ \\
\hline Constant & $\begin{array}{c}-164.4^{* * *} \\
(-2.85)\end{array}$ & $\begin{array}{c}-56.2 \\
(-1.12)\end{array}$ & $\begin{array}{c}-85.1^{* *} \\
(-2.05)\end{array}$ & $\begin{array}{c}-193.6^{* * *} \\
(-3.75)\end{array}$ & $\begin{array}{r}-111.3^{* *} \\
(-2.15)\end{array}$ & $\begin{array}{c}101.7^{* *} \\
(-2.46)\end{array}$ & $\begin{array}{c}-109.9^{* *} \\
(-2.49)\end{array}$ \\
\hline $\operatorname{Ln}($ Size $)$ & $\begin{array}{l}3.0^{*} \\
(0.19)\end{array}$ & $\begin{array}{c}27.3^{*} \\
(1.77)\end{array}$ & $\begin{array}{c}19.4 \\
(1.35)\end{array}$ & $\begin{array}{l}18.2 \\
(1.47)\end{array}$ & $\begin{array}{c}18.3 \\
(1.31)\end{array}$ & $\begin{array}{l}12.5 \\
(0.83)\end{array}$ & $\begin{array}{c}14.8 \\
(1.04)\end{array}$ \\
\hline Public & $\begin{array}{l}-22.9 \\
(-0.93)\end{array}$ & $\begin{array}{l}-32.0 \\
(-1.25)\end{array}$ & $\begin{array}{l}-29.6 \\
(-1.20)\end{array}$ & $\begin{array}{l}-22.7 \\
(-0.95)\end{array}$ & $\begin{array}{l}-26.7 \\
(-1.08)\end{array}$ & $\begin{array}{l}28.2 \\
(-1.15)\end{array}$ & $\begin{array}{l}-28.6 \\
(-1.16)\end{array}$ \\
\hline DBPlan & $\begin{array}{c}13.8 \\
(0.57)\end{array}$ & $\begin{array}{c}12.4 \\
(0.50)\end{array}$ & $\begin{array}{l}-11.3 \\
(-0.46)\end{array}$ & $\begin{array}{l}33.2 \\
(1.35)\end{array}$ & $\begin{array}{c}12.8 \\
(0.52)\end{array}$ & $\begin{array}{l}10.7 \\
(0.44)\end{array}$ & $\begin{array}{c}13.3 \\
(0.54)\end{array}$ \\
\hline ClosedFund & $\begin{array}{l}2.5 \\
(0.11)\end{array}$ & $\begin{array}{l}-0.3 \\
(-0.01)\end{array}$ & $\begin{array}{l}-0.4 \\
(-0.01)\end{array}$ & $\begin{array}{l}11.6 \\
(0.51)\end{array}$ & $\begin{array}{l}3.9 \\
(0.16)\end{array}$ & $\begin{array}{l}-4.1 \\
(-0.17)\end{array}$ & $\begin{array}{l}6.1 \\
(0.26)\end{array}$ \\
\hline Autonomous & $\begin{array}{l}17.0 \\
(0.67)\end{array}$ & $\begin{array}{l}-14.3 \\
(0.56)\end{array}$ & $\begin{array}{l}18.4 \\
(0.71)\end{array}$ & $\begin{array}{c}-11.2 \\
(-0.43)\end{array}$ & $\begin{array}{l}14.5 \\
(0.57)\end{array}$ & $\begin{array}{l}20.6 \\
(0.80)\end{array}$ & $\begin{array}{c}12.2 \\
(0.48)\end{array}$ \\
\hline RatioAP & $\begin{array}{r}0.20 \\
(0.73)\end{array}$ & $\begin{array}{r}0.26 \\
(0.94)\end{array}$ & $\begin{array}{r}0.24 \\
(0.89)\end{array}$ & $\begin{array}{r}0.16 \\
(0.61)\end{array}$ & $\begin{array}{r}0.19 \\
(0.68)\end{array}$ & $\begin{array}{r}0.24 \\
(0.89)\end{array}$ & $\begin{array}{r}0.28 \\
(1.01)\end{array}$ \\
\hline AMCosts & $\begin{array}{l}-1.19 \\
(-1.40)\end{array}$ & $\begin{array}{l}-0.95 \\
(-1.10)\end{array}$ & $\begin{array}{l}-0.93 \\
(-1.09)\end{array}$ & $\begin{array}{l}-1.14 \\
(-1.38)\end{array}$ & $\begin{array}{l}-0.96 \\
(-1.12)\end{array}$ & $\begin{array}{l}-1.17 \\
(-1.37)\end{array}$ & $\begin{array}{l}-1.20 \\
(-1.39)\end{array}$ \\
\hline AdminCosts & $\begin{array}{r}0.18 \\
(0.22)\end{array}$ & $\begin{array}{r}0.28 \\
(0.33)\end{array}$ & $\begin{array}{r}0.30 \\
(0.37)\end{array}$ & $\begin{array}{l}-0.04 \\
(-0.05)\end{array}$ & $\begin{array}{r}0.25 \\
(0.31)\end{array}$ & $\begin{array}{r}0.19 \\
(0.23)\end{array}$ & $\begin{array}{r}0.27 \\
(-0.32)\end{array}$ \\
\hline $\mathrm{R}^{2}$ adj. & 0.045 & 0.014 & 0.017 & 0.086 & 0.023 & 0.030 & 0.031 \\
\hline
\end{tabular}

Notes: The table shows the results of the regressions (1-7) of our model on the 3-year arithmetic mean of the difference between the net fund return and the return of the pension funds' individual policy benchmarks for the period 2010-2012 (TE_PolicyBenchmark). Adjusted $\mathrm{R}^{2} \mathrm{~s}$ of the models are shown in the bottom line of the table. T-statistics are shown in parentheses. Coefficient estimates are reported in basis points. The results are based on 139 observations.

*** $1 \%$ significance; ${ }^{* *} 5 \%$ significance; ${ }^{*} 10 \%$ significance. 
desirable in order to avoid conflicts of interests, their relationship to performance is not statistically measurable.

We furthermore find no conclusive evidence for a relationship between the degree of transparency, as measured by our MOTR Score, and excess returns or average benchmark outperformance. While transparency is an important governance variable that aims to protect the interests of plan members, "soft" factors such as the disclosure of board members' additional mandates or peer group benchmarking practices have no direct effect on plan performance. Although neither directly associated with the investment process, we do find some evidence that the design of management objectives is related to both mean excess returns and outperformance as measured by the variable TE_AllocationBenchmark. The statistical significance of those results is weak, however. The analysis of the individual score constituents of the MANO Score reveals that particularly the existence of an own mission statement drives the results. Pension funds in our sample that have an own written statement regarding their overall strategic goals have a higher average excess return by approximately 41 basis points and have positively deviated from the passive benchmark by around 44 basis points on average during the evaluation period. Board and senior management compensation policies, by contrast, do not have any measurable effect.

To account for different portfolio risk structures, we finally regress Sharpe ratios on our model. The results in Table 16 show that governance is also positively related to the risk-adjusted excess returns. The significant positive coefficient estimates for both the TSIS Score and the RIMA Score clearly underpin this. Hence, regardless of which performance measure employed, we find that superior investment performance, both on a non-risk adjusted and risk-adjusted basis, seems to be particularly related to a pension fund's target setting and investment strategy definition process and, yet to lesser extent, its risk management design. Organisational structure, investment processes, and transparency are found to be less important for performance.

Lastly, in opposite to the findings of Andonov, BAuER, and Cremers (2011), we find that tactical asset allocation is detrimental for the funds in our sample. The coefficient estimate for this TSIS Score constituent is significantly negative for the variables ExcessReturn and TE_AllocationBenchmark, indicating that short-term fluctuations from the policy structure rather destroy than add value for plan beneficiaries. This implies that the sample plan managers were not able to achieve persistent gains from market timing or security selection practices during the evaluation period. Due to the relatively large coefficient standard errors, the statistical validity of this result is somewhat limited, however. For the variable Sharpe, no statistically significant effect is found. 
Table 16: Governance and Sharpe Ratios

Dependent Variable $=$ Sharpe

\begin{tabular}{|c|c|c|c|c|c|c|c|}
\hline & 1 & 2 & 3 & 4 & 5 & 6 & 7 \\
\hline G-SCORE & $\begin{array}{l}0.004^{*} \\
(1.92)\end{array}$ & & & & & & \\
\hline ORGA Score & & $\begin{array}{l}0.002 \\
(0.16)\end{array}$ & & & & & \\
\hline MANO Score & & & $\begin{array}{l}0.023^{* *} \\
(2.39)\end{array}$ & & & & \\
\hline TSIS Score & & & & $\begin{array}{l}0.024^{* *} \\
(2.40)\end{array}$ & & & \\
\hline INVP Score & & & & & $\begin{array}{l}0.013 \\
(0.14)\end{array}$ & & \\
\hline RIMA Score & & & & & & $\begin{array}{l}0.007 \\
(1.58)\end{array}$ & \\
\hline MOTR Score & & & & & & & $\begin{array}{l}0.003 \\
(0.25)\end{array}$ \\
\hline Constant & $\begin{array}{l}0.189^{* *} \\
(2.22)\end{array}$ & $\begin{array}{l}0.326^{* * *} \\
(4.80)\end{array}$ & $\begin{array}{l}0.259^{* * *} \\
(5.29)\end{array}$ & $\begin{array}{l}0.177^{* *} \\
(2.34)\end{array}$ & $\begin{array}{l}0.327^{* *} \\
(-4.55)\end{array}$ & $\begin{array}{l}0.270^{* * *} \\
(4.84)\end{array}$ & $\begin{array}{l}0.323^{* * *} \\
(5.40)\end{array}$ \\
\hline $\operatorname{Ln}($ Size $)$ & $\begin{array}{l}0.007 \\
(0.33)\end{array}$ & $\begin{array}{l}0.033 \\
(1.48)\end{array}$ & $\begin{array}{l}0.011 \\
(0.54)\end{array}$ & $\begin{array}{l}0.032^{*} \\
(1.82)\end{array}$ & $\begin{array}{l}0.034^{*} \\
(1.75)\end{array}$ & $\begin{array}{l}0.018 \\
(0.88)\end{array}$ & $\begin{array}{l}0.033^{*} \\
(1.68)\end{array}$ \\
\hline Public & $\begin{array}{l}0.028 \\
(0.75)\end{array}$ & $\begin{array}{l}0.020 \\
(0.52)\end{array}$ & $\begin{array}{l}0.020 \\
(0.55)\end{array}$ & $\begin{array}{l}0.026 \\
(0.70)\end{array}$ & $\begin{array}{l}0.019 \\
(0.51)\end{array}$ & $\begin{array}{l}0.021 \\
(0.56)\end{array}$ & $\begin{array}{l}0.019 \\
(0.51)\end{array}$ \\
\hline DBPlan & $\begin{array}{l}-0.077^{* *} \\
(-2.06)\end{array}$ & $\begin{array}{l}-0.801^{* *} \\
(-2.12)\end{array}$ & $\begin{array}{l}-0.085^{* *} \\
(-2.29)\end{array}$ & $\begin{array}{l}-0.056 \\
(-1.46)\end{array}$ & $\begin{array}{l}-0.080^{* *} \\
(-2.10)\end{array}$ & $\begin{array}{l}-0.081^{* *} \\
(-2.16)\end{array}$ & $\begin{array}{l}-0.079^{* *} \\
(-2.10)\end{array}$ \\
\hline ClosedFund & $\begin{array}{l}-0.012 \\
(-0.34)\end{array}$ & $\begin{array}{l}-0.160 \\
(-0.45)\end{array}$ & $\begin{array}{l}-0.019 \\
(-0.54)\end{array}$ & $\begin{array}{l}-0.000 \\
(-0.01)\end{array}$ & $\begin{array}{l}-0.015 \\
(-0.43)\end{array}$ & $\begin{array}{l}-0.002 \\
(-0.61)\end{array}$ & $\begin{array}{l}-0.015 \\
(-0.41)\end{array}$ \\
\hline Autonomous & $\begin{array}{l}0.004 \\
(0.10)\end{array}$ & $\begin{array}{l}-0.003 \\
(-0.07)\end{array}$ & $\begin{array}{l}0.015 \\
(0.41)\end{array}$ & $\begin{array}{l}-0.277 \\
(-0.72)\end{array}$ & $\begin{array}{l}-0.003 \\
(-0.08)\end{array}$ & $\begin{array}{l}0.001 \\
(0.24)\end{array}$ & $\begin{array}{l}-0.003 \\
(-0.09)\end{array}$ \\
\hline $\mathrm{R}^{2}$ adj. & 0.045 & 0.028 & 0.069 & 0.069 & 0.028 & 0.046 & 0.028 \\
\hline
\end{tabular}

Notes: The table shows the results of the regressions (1-7) of our model on the pension funds' Sharpe ratios for the period 2010-2012 (Sharpe). Adjusted R ${ }^{2} s$ of the models are shown in the bottom line of the table. T-statistics are shown in parentheses. Coefficient estimates are reported in basis points. 3 pension funds with Sharpe ratios in excess of 1 have been excluded. The results are based on 136 observations.

${ }^{* * *} 1 \%$ significance; ${ }^{* *} 5 \%$ significance; ${ }^{*} 10 \%$ significance. 
To relate pension fund governance to asset allocation decisions, we run Tobit regressions of the pension funds' effective asset class weights as of the end of 2012 on the G-SCORE and control variables. Table 17 shows the summary statistics of the realised asset allocation weights. Table 18 shows the results of this examination. While we find some evidence that governance is negatively related to the proportion of domestic equity investments, our analysis reveals that asset allocation decisions are not primarily associated with governance structure, but rather with size, legal form, and a pension fund's ratio of active members to retirees. As shown in Table 18, the Swiss pension funds in our sample invest on average around $0.17 \%$ less in equities denominated in Swiss franc for each G-SCORE point. This might be explained by the fact that plans with high G-SCOREs do have more comprehensive risk management systems in place that allow them to invest a larger proportion of their funds in foreign assets which entail additional risk factors ${ }^{10}$. In fact, the analysis of the individual constituent sub-scores reveals that primarily RIMA and ORGA drive those results. Apart from governance, particularly size seems to be an important factor affecting asset allocation. Our analysis shows that larger funds invest a substantially larger proportion of their assets in foreign equities $(+4.32 \%)$ and alternative investments $(+3.61 \%)$. Since some alternative asset classes such as specialised hedge funds or closed-end private equity funds often require a high minimum investment amount, this finding has economic justification. Diversification considerations let smaller funds refrain from such investments. Furthermore, we find strong evidence that larger pension funds allocate a larger fraction of their investable funds to equities and invest less in real estate (domestic and foreign) and liquid cash holdings. This finding indicates that they generally opt for riskier asset classes which might additionally explain their higher mean excess returns in the evaluation period. Some part of their superior excess performance hence might come at the cost of higher risk and asset volatility. Since larger pension schemes have more institutionalised risk management structures that allow them to control riskier investments, such asset allocation decisions are evident from an economic point of view.

In addition to plan size, we find that both a pension fund's legal form and its relation of active members to pensioners are related to its asset allocation decisions. Our empirical results show that pension arrangements that are set up under public law invest around $6.6 \%$ more in domestic real estate and hold a significantly larger part of employer investments (primarily in the form of federal government, cantonal, or municipal bonds). The regression estimates furthermore

E.g., such as currency risks, political risks, etc. 
Table 17: Descriptive Statistics of Realised Asset Allocation Weights

\begin{tabular}{lrrrrc}
\hline Asset Class & Mean & Median & SD & Min & Max \\
\hline Cash & $7.5 \%$ & $5.5 \%$ & $6.5 \%$ & $0.0 \%$ & $37.0 \%$ \\
InvEmp & $1.0 \%$ & $0.0 \%$ & $3.1 \%$ & $0.0 \%$ & $28.5 \%$ \\
BondsDom & $24.3 \%$ & $24.0 \%$ & $12.2 \%$ & $0.0 \%$ & $50.3 \%$ \\
BondsFX & $12.1 \%$ & $5.0 \%$ & $7.2 \%$ & $3.9 \%$ & $50.8 \%$ \\
Mortg & $1.6 \%$ & $0.0 \%$ & $2.8 \%$ & $0.0 \%$ & $11.1 \%$ \\
EquityDom & $11.7 \%$ & $11.4 \%$ & $5.6 \%$ & $0.0 \%$ & $35.6 \%$ \\
EquityFX & $15.6 \%$ & $13.0 \%$ & $7.7 \%$ & $0.0 \%$ & $42.0 \%$ \\
REDom & $19.4 \%$ & $17.7 \%$ & $10.6 \%$ & $0.0 \%$ & $63.6 \%$ \\
REFX & $1.4 \%$ & $0.0 \%$ & $1.5 \%$ & $0.0 \%$ & $9.1 \%$ \\
AI & $4.5 \%$ & $3.3 \%$ & $5.2 \%$ & $0.0 \%$ & $36.8 \%$ \\
Other & $0.8 \%$ & $0.0 \%$ & $2.1 \%$ & $0.0 \%$ & $15.8 \%$ \\
\hline
\end{tabular}

Notes: The table shows the descriptive statistics of the sample pension fund's realised asset allocation weights as of the end of 2012. Asset classes are defined as follows: CHF cash holdings (=Cash); Investments with the employer (=InvEmp); Bonds denominated in CHF (=BondsDom); Bonds denominated in foreign currencies $(=$ BondsFX); Mortgages (= Mortg); Equities denominated in $\mathrm{CHF}$ (=EquityDom); Equities denominated in foreign currencies (=EquitxFX); Real estate investments denominated in CHF (=REDom); Real estate investments denominated in foreign currencies (=REFX); Alternative investments $(=\mathrm{AI})$; Figures are reported in \%. The statistics are based on the allocations of all 139 pension funds in our sample.

indicate that public pension funds grant more mortgages than private pension funds and allocate less capital to foreign equities and domestic bonds. This might be an indication for a home bias tendency. Our findings show that staterun pension schemes tend to exhibit a rather domestic investment focus regarding real estate and equity investments. Although our results point to a negative relationship between public funds and domestic bond allocations, there is some evidence that state-run plans substitute domestic bonds with government or municipal bonds that are to be classified as investments with the employer under their investment statutes. 
Table 18: Determinants of Asset Allocation Weights

\begin{tabular}{|c|c|c|c|c|c|c|c|c|c|c|c|}
\hline $\begin{array}{l}\text { Dependent } \\
\text { Variable }\end{array}$ & Cash & InvEmp & BondsDom & BondsFX & Mortg & EquityDom & EquityFX & REDom & REFX & AI & Other \\
\hline G-SCORE & $\begin{array}{l}5.7 \\
(0.68)\end{array}$ & $\begin{array}{l}1.4 \\
(0.18)\end{array}$ & $\begin{array}{l}7.6 \\
(0.50)\end{array}$ & $\begin{array}{l}6.7 \\
(0.63)\end{array}$ & $\begin{array}{l}-3.0 \\
(-0.35)\end{array}$ & $\begin{array}{c}-16.7^{* *} \\
(-2.39)\end{array}$ & $\begin{array}{l}-0.1 \\
(-0.01)\end{array}$ & $\begin{array}{l}10.8 \\
(0.80)\end{array}$ & $\begin{array}{l}-0.9 \\
(-0.17)\end{array}$ & $\begin{array}{l}-4.1 \\
(-0.48)\end{array}$ & $\begin{array}{l}-8.9 \\
(-1.45)\end{array}$ \\
\hline Constant & $\begin{array}{l}485.2 \\
(1.49)\end{array}$ & $\begin{array}{r}-384.5 \\
(-1.25)\end{array}$ & $\begin{array}{c}2,808.9^{* * *} \\
(4.77)\end{array}$ & $\begin{array}{c}886.2^{* *} \\
(2.14)\end{array}$ & $\begin{array}{r}130.4 \\
(0.40)\end{array}$ & $\begin{array}{c}1,599.7^{* * *} \\
(5.92)\end{array}$ & $\begin{array}{c}1,682.7^{* * *} \\
(4.40)\end{array}$ & $\begin{array}{r}1,106.8^{* *} \\
(2.12)\end{array}$ & $\begin{array}{l}77.1 \\
(0.37)\end{array}$ & $\begin{array}{c}691.4^{* *} \\
(2.13)\end{array}$ & $\begin{array}{l}77.7 \\
(0.32)\end{array}$ \\
\hline $\operatorname{Ln}($ Size $)$ & $\begin{array}{c}-219.2^{* *} \\
(-2.48)\end{array}$ & $\begin{array}{l}-28.5 \\
(-0.35)\end{array}$ & $\begin{array}{r}-103.7 \\
(-0.65)\end{array}$ & $\begin{array}{l}48.7 \\
(0.43)\end{array}$ & $\begin{array}{r}164.5^{*} \\
(1.86)\end{array}$ & $\begin{array}{r}-156.3 \\
(-2.13)\end{array}$ & $\begin{array}{c}431.5^{* * *} \\
(4.15)\end{array}$ & $\begin{array}{r}-373.6^{* *} \\
(-2.64)\end{array}$ & $\begin{array}{l}83.5 \\
(1.52)\end{array}$ & $\begin{array}{c}361.4^{* * *} \\
(4.07)\end{array}$ & $\begin{array}{l}59.3 \\
(0.86)\end{array}$ \\
\hline Public & $\begin{array}{l}28.9 \\
(0.20)\end{array}$ & $\begin{array}{c}404.3^{* * *} \\
(3.08)\end{array}$ & $\begin{array}{c}-525.3^{* *} \\
(-2.01)\end{array}$ & $\begin{array}{r}-178.4 \\
(-0.97)\end{array}$ & $\begin{array}{c}285.6^{* *} \\
(2.17)\end{array}$ & $\begin{array}{l}123.0 \\
(1.02)\end{array}$ & $\begin{array}{c}-352.9^{* *} \\
(-2.08)\end{array}$ & $\begin{array}{c}660.6^{* * *} \\
(2.86)\end{array}$ & $\begin{array}{l}88.2 \\
(1.02)\end{array}$ & $\begin{array}{l}-71.2 \\
(-0.49)\end{array}$ & $\begin{array}{l}59.6 \\
(0.52)\end{array}$ \\
\hline DBPlan & $\begin{array}{l}115.5 \\
(0.81)\end{array}$ & $\begin{array}{r}-179.0 \\
(-1.31)\end{array}$ & $\begin{array}{c}-816.2^{* * *} \\
(-3.13)\end{array}$ & $\begin{array}{r}310.8^{*} \\
(1.72)\end{array}$ & $\begin{array}{l}37.5 \\
(0.29)\end{array}$ & $\begin{array}{l}129.6 \\
(1.10)\end{array}$ & $\begin{array}{r}316.2^{*} \\
(1.89)\end{array}$ & $\begin{array}{l}-51.2 \\
(-0.22)\end{array}$ & $\begin{array}{l}-41.9 \\
(-0.47)\end{array}$ & $\begin{array}{l}-75.6 \\
(-0.52)\end{array}$ & $\begin{array}{r}-250.6^{* *} \\
(-2.01)\end{array}$ \\
\hline ClosedFund & $\begin{array}{l}-97.8 \\
(-0.73)\end{array}$ & $\begin{array}{r}225.2^{*} \\
\quad(1.76)\end{array}$ & $\begin{array}{r}-404.4 \\
(-0.71)\end{array}$ & $\begin{array}{l}-70.5 \\
(-0.41)\end{array}$ & $\begin{array}{c}-258.9^{* *} \\
(-2.16)\end{array}$ & $\begin{array}{l}16.6 \\
(0.15)\end{array}$ & $\begin{array}{l}31.9 \\
(0.20)\end{array}$ & $\begin{array}{r}424.2^{*} \\
(1.97)\end{array}$ & $\begin{array}{l}-35.8 \\
(-0.44)\end{array}$ & $\begin{array}{l}66.4 \\
(0.50)\end{array}$ & $\begin{array}{r}177.0 \\
(1.53)\end{array}$ \\
\hline Autonomous & $\begin{array}{r}120.8 \\
(0.83)\end{array}$ & $\begin{array}{r}-62.2 \\
(-0.45)\end{array}$ & $\begin{array}{r}-188.7 \\
(-0.71)\end{array}$ & $\begin{array}{r}185.7 \\
(1.00)\end{array}$ & $\begin{array}{l}-91.1 \\
(-0.63)\end{array}$ & $\begin{array}{l}95.6 \\
(0.79)\end{array}$ & $\begin{array}{r}-162.0 \\
(-0.94)\end{array}$ & $\begin{array}{r}128.3 \\
(0.55)\end{array}$ & $\begin{array}{c}-34.0 \\
(-0.36)\end{array}$ & $\begin{array}{r}-259.2^{*} \\
(-1.75)\end{array}$ & $\begin{array}{r}-105.2 \\
(-0.95)\end{array}$ \\
\hline RatioAP & $\begin{array}{l}3.6^{* *} \\
(2.27)\end{array}$ & $\begin{array}{l}-2.0 \\
(-0.83)\end{array}$ & $\begin{array}{l}7.5^{* * *} \\
(2.65)\end{array}$ & $\begin{array}{l}0.1 \\
(0.07)\end{array}$ & $\begin{array}{l}0.9 \\
(0.65)\end{array}$ & $\begin{array}{l}-3.5^{* * *} \\
(-2.68)\end{array}$ & $\begin{array}{l}-0.8 \\
(-0.43)\end{array}$ & $\begin{array}{l}-8.6^{* * *} \\
(-2.82)\end{array}$ & $\begin{array}{l}-1.7 \\
(-0.82)\end{array}$ & $\begin{array}{l}-9.0 \\
(-1.57)\end{array}$ & $\begin{array}{l}1.3 \\
(1.23)\end{array}$ \\
\hline Pseudo $\mathrm{R}^{2}$ adj & 0.008 & 0.013 & 0.015 & 0.004 & 0.029 & 0.016 & 0.017 & 0.011 & 0.001 & 0.020 & 0.015 \\
\hline
\end{tabular}

Notes: The table shows the results of the Tobit regressions of our model on the effective asset allocation weights as of the end of 2012 of the pension funds in our sample. Individual asset class allocations are taken as dependent variables. Asset classes are defined as follows: CHF cash holdings (=Cash); Investments with the employer (=InvEmp); Bonds denominated in CHF (=BondsDom); Bonds denominated in foreign currencies (=BondsFX); Mortgages (= Mortg); Equities denominated in CHF (=EquityDom); Equities denominated in foreign currencies $(=\mathrm{Equitx} F \mathrm{XX}$ ); Real estate investments denominated in CHF (=REDom); Real estate investments denominated in foreign currencies (=REFX); Alternative investments $(=\mathrm{AI})$; Figures are reported in basis points. The regressions are based on the allocations of all 139 pension funds in our sample.

*** $1 \%$ significance; ${ }^{* *} 5 \%$ significance; ${ }^{*} 10 \%$ significance. 


\section{Conclusion}

This paper examines the relationship between governance structures, investment performance, and asset allocation decisions of occupational pension plans in Switzerland. Based on survey responses from 139 entities, we find empirical evidence that pension fund governance is positively related to investment performance, but only marginally to the funds' asset class choices. This has important implications for the industry in that it shows that the establishment of comprehensive governance structures might directly benefit plan members. While our study does not give any indication of the direction of causality, however, it shows that good governance pertaining to target setting, investment strategy definition, and risk management design is positively related to both excess- and riskadjusted net fund returns. For our analysis, we draw on four different portfolio performance measures: 1) average excess return, 2) passive benchmark outperformance, 3) individual benchmark outperformance, and 4) Sharpe ratio. Regardless of which particular measure we employ, we find both statistically and economically significant positive effects for the composite G-SCORE metric, as well as for the sub-scores that cover target setting and investment strategy and risk management. The investigation of those individual sub-score components furthermore shows that particularly independent external experts that participate in investment strategy meetings are associated with superior performance. Risk management design is also found to be an important factor that is related to net investment performance. While we find a positive relationship between comprehensive risk management practices and excess returns and passive benchmark deviations, we do not find statistically significant effects when analysing Sharpe ratios. The analysis of the individual score components for the management objectives score (MANO Score) furthermore reveals that a clear specification of organisational goals and strategic targets by means of a written mission statement is positively related to passive benchmark outperformance.

For investment allocation decisions, we find that governance structures are only of little importance. The 2012 year-end asset allocation weights of our sample pension portfolios are primarily related to institutional factors such as size, legal form, and the ratio of active plan members to pensioners. We do not find conclusive empirical evidence that governance is related to those realised allocation weights. 


\section{Appendix}

Appendix 1: Composition of the Passive Benchmark Strategy (SAA Return)

\begin{tabular}{|c|c|}
\hline Asset Class & Benchmark Index \\
\hline Cash & 3-Month CHF Libor \\
\hline Investments with Employer - Loans & SBI Domestic AAA-BBB Total Return Index* \\
\hline Investments with Employer - Equity & Swiss All Share Index \\
\hline Bonds - in CHF & SBI Total AAA-BBB Total Return Index** \\
\hline Bonds - Foreign currency & $\begin{array}{l}\text { Barclays Global Aggregate Total Return Index } \\
\text { (unhedged) }\end{array}$ \\
\hline Bonds - Foreign currency hedged & $\begin{array}{l}\text { Barclays Global Aggregate Total Return Index } \\
\text { (CHF-hedged) }\end{array}$ \\
\hline Equity - Switzerland in CHF & Swiss Performance Index \\
\hline Equity - Foreign currency & $\begin{array}{l}\text { MSCI World ex Switzerland Total Return Index } \\
\text { (unhedged) }\end{array}$ \\
\hline Equity - Foreign currency hedged & $\begin{array}{l}\text { MSCI World ex Switzerland Total Return Index } \\
\text { (CHF-hedged) }\end{array}$ \\
\hline Mortgages & SNB Average Swiss Mortgage Rate \\
\hline Real Estate - Switzerland in $\mathrm{CHF}^{* * *}$ & KGAST Immo Index \\
\hline Real Estate - Switzerland in $\mathrm{CHF}^{* * *}$ & DB Rüd Blass Swiss Real Estate Fund Index \\
\hline Real Estate - Switzerland in $\mathrm{CHF}^{* * *}$ & SIX Real Estate Funds Total Return Index \\
\hline Real Estate - Foreign currency & Dow Jones Global Select Real Estate Securities Index \\
\hline Alternative Investments - Private Equity & LPX Composite Total Return Index \\
\hline Alternative Investments - Hedge Funds & HFRX Global Hedge Fund Index \\
\hline Alternative Investments - Commodities & Dow Jones UBS Commodity TR Index \\
\hline Alternative Investments - Infrastructure & MSCI World Infrastructure Index \\
\hline Alternative Investments - Other & HFRX Equal Weighted Strategies Index \\
\hline Other Assets & 12-Month CHF Libor \\
\hline Risk-free rate & $\begin{array}{l}\text { Yield on 10yr Swiss Confederation Bonds (annual } \\
\text { average) }\end{array}$ \\
\hline
\end{tabular}

Notes: The table shows the composition of the passive benchmark strategy. The indices proxy the performance of the major asset classes.

* Index data available since 2007; for the years prior to 2007, we use the old SBI Domestic Total Return Index.

** Index data available since 2007; for the years prior to 2007, we use the old SBI Total Return Index.

*** The benchmark data for the asset class "Real Estate - Switzerland in CHF" is composed of all three indices with equal weight. 


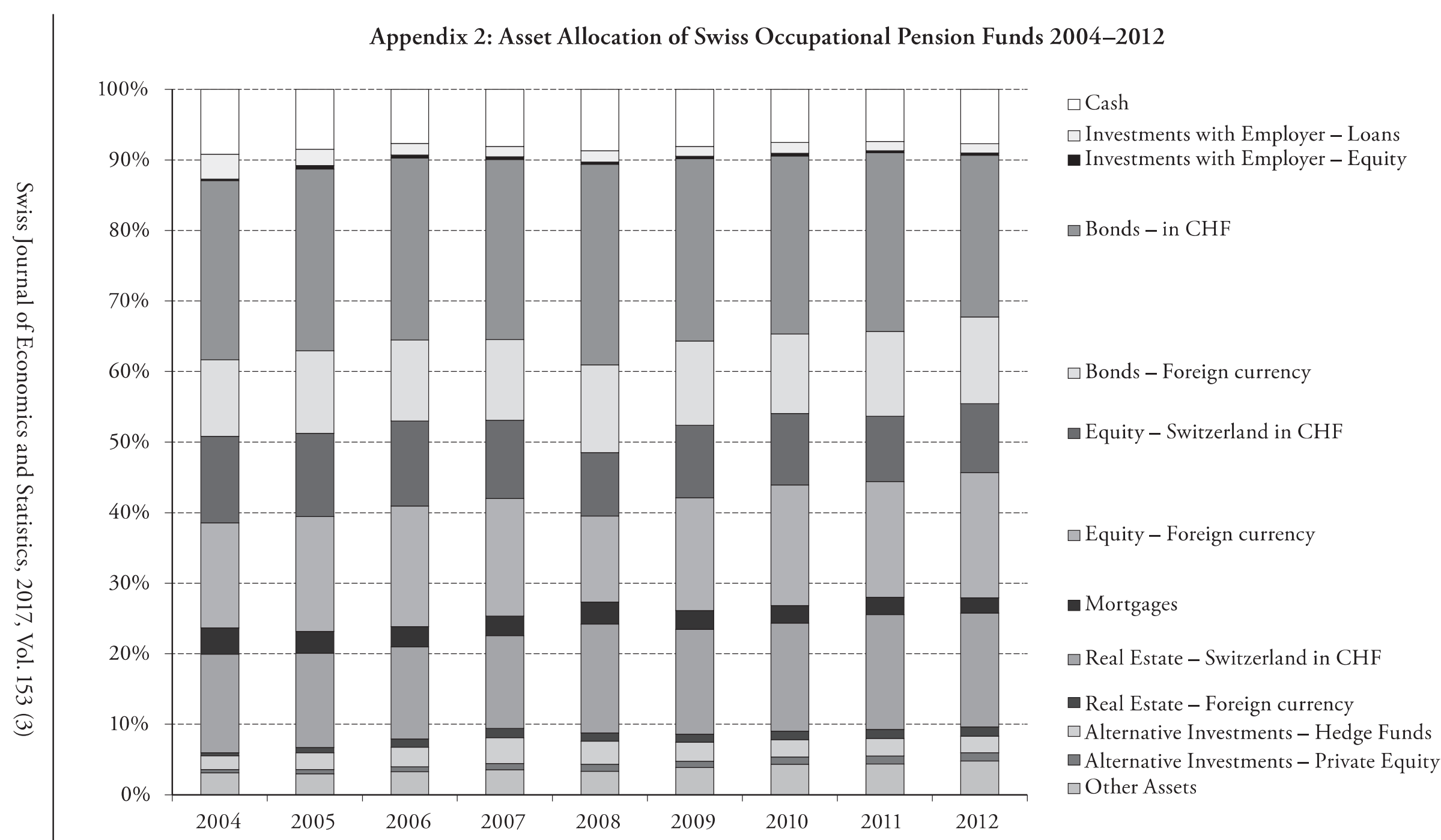

Notes: The figure shows the aggregated asset allocation weights of all Swiss occupational pension funds for the years 2004-2012. Data is retrieved from the Swiss Federal Statistical Office (2014). 


\section{Appendix 3: Variables and Explanations}

\begin{tabular}{|c|c|}
\hline G-SCORE & Composite Pension Fund Governance Score \\
\hline ORGA Score & Sub-Score 1: Organisation Score \\
\hline MANO Score & Sub-Score 2: Management Objectives Score \\
\hline TSIS Score & Sub-Score 3: Target Setting and Investment Strategy Score \\
\hline INVP Score & Sub-Score 4: Investment Process Score \\
\hline RIMA Score & Sub-Score 5: Risk Management Score \\
\hline MOTR Score & Sub-Score 6: Monitoring and Transparency Score \\
\hline $\operatorname{Ln}($ Size $)$ & Natural logarithm of average pension fund size (2010-2012) \\
\hline Public & $\begin{array}{l}\text { Dummy variable assuming } 1 \text { if pension fund is a public pension } \\
\text { fund }\end{array}$ \\
\hline DBPlan & $\begin{array}{l}\text { Dummy variable assuming } 1 \text { if pension fund is a defined } \\
\text { benefit plan }\end{array}$ \\
\hline ClosedFund & Dummy variable assuming 1 if pension fund is a closed fund \\
\hline Autonomous & Dummy variable assuming 1 if pension fund is autonomous \\
\hline RatioAP & Average ratio of active participants to pensioners (2010-2012) \\
\hline AMCosts & Average direct asset management costs (2010-2012) \\
\hline AdminCosts & Average administration costs (2010-2012) \\
\hline ExcessReturn & Geometric mean return in excess of the risk-free rate* \\
\hline TE_AllocationBenchmark & $\begin{array}{l}\text { Arithmetic mean of the annual deviations from the passive } \\
\text { benchmark (2010-2012) }\end{array}$ \\
\hline TE_PolicyBenchmark & $\begin{array}{l}\text { Arithmetic mean of the annual deviations from the individual } \\
\text { benchmark (2010-2012) }\end{array}$ \\
\hline Sharpe & Sharpe ratio of the pension funds** \\
\hline
\end{tabular}

Notes: The table shows the variables used in the regressions and their detailed explanations.

* as proxied by the average yield of the 10-year Swiss confederation bond.

** as computed as the difference of the pension plans' geometric mean return of the years 20102012 and the risk-free rate as proxied by the geometric annual average yield of 10-year Swiss confederation bonds divided by the pension funds' annual volatility for the 10-year period. 


\section{Construction of the G-SCORE: Details on the Components}

\section{A1) Organisation Score (ORGA)}

The OECD Guidelines for Pension Fund Governance recommend clear identification and assignment of responsibilities. Since clear lines of authority are an essential component of good pension fund governance, we argue that Swiss pension funds should have organisational regulations that explicitly allocate the most important areas of responsibilities to the their governing bodies $(1)^{11}$. Clear separation of power between those bodies might furthermore contribute to transparency in decision-making and reduce the risks of fraud and management misconduct. Therefore, we punish pension funds whose board members hold both executive and supervisory functions (1). To ensure a high degree of objectivity and independence in decision-making and monitoring, the supervisory body might consider establishing specialised board committees that are assigned with specific tasks. WRIGHT et al. (2013) describe that sub-committees are effective in bringing greater specialisation and objectivity by board members as well as greater attention to discrete issues. The Organisation Score therefore rewards pension funds whose board structure includes sub-committees (1).

To effectively steer their business operations, many occupational pension schemes in Switzerland employ a full-time CEO who is solely in charge of pension fund issues. However, smaller pension funds often assign the administration responsibility to one (or several) employee(s) of the sponsor firm, who dedicate part of their working time to pension fund matters since employing a full-time CEO would be disproportionately costly. The decision of whether a full-time CEO is economically sensible or not thus needs to be made in light of a pension fund's size. The Organisation Score hence rewards smaller funds and punishes larger funds for not having a CEO who dedicates $100 \%$ of his employment time to pension issues $(1)^{12}$.

In addition to the executive officers, the board of trustees plays a key role in occupational pension fund governance. Its main functions are the definition and implementation of the pension plan's investment strategy, the advisory of the $\mathrm{CEO}$, and the ongoing monitoring of activities in the best interest of the scheme's stakeholders. Corporate governance literature on board structure points to a negative relationship between board size and firm performance. It is argued that

11 E.g., by means of an activity distribution matrix or management organisation chart.

12 Large pension funds are defined as having plan assets in excess of 1,000 $\mathrm{mn}$ CHF as averaged over the years 2010-2012 whereas small funds are those with less than 1,000 mn CHF assets under management. 
large boards are less effective than small boards due to coordination and agency problems ${ }^{13}$. For U.S. pension funds, Impavido (2002) claims that the number of trustees should be limited, as this reduces individual free-riding incentives and thus maximises board effectiveness. HARPER (2008) finds a negative statistical relationship between trustee board size and funding levels of U.S. public pension plans. We apply this literature to occupational pension schemes in Switzerland. In line with those findings, we hypothesize that trustee board size is negatively related to the investment performance of Swiss pension funds ${ }^{14}$. However, while we also acknowledge that large boards might be more difficult to manage and are thus less effective, we challenge the notion that there is an absolute number of trustees that is optimal (as suggested by CLARK and URWIN, 2008) irrespective of the size of the fund. Since we expect that larger pension funds will naturally have larger trustee boards, we decline a "one-size-fits-all" approach and put board size in relation to pension fund size. The Organisation Score therefore rewards pension funds with plan assets of less than 100 million CHF: for having not more than 6 trustee board members; with plan assets in excess of 100 million CHF, but less than 1,000 million CHF: for having not more than 8 trustee board members; and with plan assets in excess of 1,000 million CHF: for having not more than 12 trustee board members. The above-stated size thresholds are based on the sample means of the respective pension fund size category. Disproportionate deviations from the average number of trustees can thus be detected in a relatively simple manner ${ }^{15}$. We follow the same logic for the size of the investment committee. Since the investment committee is also an important governance body, its dimension should be in appropriate relation to a pension plan's assets. Hence, the Organisation Score rewards pension funds with plan assets of less than 100 million CHF: for not having more than 3 investment committee members; with plan assets in excess of 100 million CHF, but less than 1,000 million CHF: for having not more than 4 investment committee members and; with plan assets in excess of 1,000 million CHF: for having not more than 6 investment committee members ${ }^{16}$.

13 See, for example, Lipton and Lorsch (1992) or Jensen (1993).

14 It should be noted that there is no regulatory minimum or maximum number of trustee board members for pension funds in Switzerland.

15 To test for robustness, those thresholds are varied in the empirical analysis (e.g., changed to the sample median of each size category, the mean or median of the entire data sample, or to the fixed numbers as recommended by CLARK and URWIN, 2008). The results of these variations are discussed in section 6.

16 If a pension fund stated to have no investment committee, no points were assigned. The size thresholds were also based on the sample mean and tested for robustness in the empirical section. 
Since the board of trustees is the key element in the management framework of Swiss pension schemes, its human capital is of critical importance for the funds' governance quality. We therefore additionally reward pension funds that have an appropriate board composition pertaining to 1) age structure and 2) trustee expertise. Age structure of boards has been a central point of interest in the corporate governance literature. Kanagaretnam, Lobo, and Whalen (2007) state that boards with older members are considered to be less efficient, as those members do not actively participate in board activities anymore. BROwN and CAYLOR (2006) provide empirical evidence. For U.S. public pension funds, Harper (2008) finds that longer board terms lead to lower net returns. Since an overaged trustee board might potentially suffer from inner inertia and lower monitoring effectiveness, our Organisation Score assigns 1 point to pension funds that have specified a mandatory retirement age provision (1). Good governance furthermore requires that all board members possess adequate qualification, knowledge, and expertise to steer and monitor the pension funds' strategic and operational activities. In the aftermath of the financial crisis this requirement has particularly gained in importance. Increasing complexity concerning pension issues and changing conditions on the global capital markets more than ever require highly qualified trustees. However, since Article 51 of the Swiss Federal Law on Occupational Old-age, Survivors' and Disability Pension Plans (BVG) calls for paritarian representation of employers and employees on the board of trustees, there is an inherent trade-off between representation and expertise within Swiss occupational pension funds. This has also been documented by CLARK (2007) for UK pension funds and U.S. mutual funds. While this is an institutional problem, it is furthermore difficult to determine an "optimal" qualification level for trustees or executives. Since an entirely objective measure for adequate qualification and expertise is difficult to define, we follow the recommendation of CLARK (2004), who proposes that pension fund trustees should optimally possess relevant professional qualifications and obtain ongoing task-specific training. In line with this recommendation, the Organisation Score rewards pension funds whose board members are solely elected on the basis of their specialised knowledge regarding pension issues $(1)^{17}$. Furthermore, we argue that it might be beneficial for pension funds to have a task-specific educational training concept for their trustees regarding 1) legal provisions and regulatory requirements, 2) the investment strategy(-ies) of the pension fund and, 3) the risk management practices of the pension fund. Since we believe that

17 i.e., no ex-officio members. 
all those topics are essential, we reward pension funds that have an education programme containing all three elements (1). In order to fill the gap of a lack of internal expertise, pension funds' governing bodies should furthermore draw on independent external specialists or consultants that are specialised in pension matters, actuarial issues, and investment management. The OECD Guidelines on Pension Fund Governance support this view by stipulating that the appointment of independent professionals to the governing body is an effective way to promote good governance (1).

\section{A2) Management Objectives Score (MANO)}

The definition of management objectives and the design of supportive incentive structures are focal points of governance systems. While literature on those aspects primarily focuses on corporate boards, we believe that corporate governance principles are also applicable for pension funds' trustee boards. Yermo and STEWART (2008) point to the problem that boards of trustees often lack a clear mission statement and engage in operational duties which should be left to internal management staff or external service providers. Since a clear specification of organisational goals helps the board to concentrate on its primary tasks, we postulate that an occupational pension fund should have an own written statement regarding its overall strategic targets (1). To reconcile strategic targets with management tasks, clear objectives should be defined for the board of trustees (1). Good pension fund governance might furthermore require incentive structures that link board member compensation to performance. Ambachtsheer, CAPELLE, and Scheibelhut (1998) persuasively argue that organisational goals should be clear and compensation policies should be related to the achievement of those goals in order to align the economic interests of plan members with the interests of management. CLARK and URWIN (2010) furthermore assert that competitive compensation structures aligned with effective performance measurement will enhance the professional competence of trustee boards. While this argumentation is persuasive in theory, the above-stated recommendations are only scarcely implemented by Swiss pension funds in reality. To investigate whether competitive incentive structures for board members are effectively related to performance and asset allocation, we hypothesise that they have a positive effect and therefore reward pension funds whose board members receive performance-linked financial compensation $(1)^{18}$. Since competitive incentive structures should not only

18 Pension funds that reported fixed financial compensation or solely reimbursement of expenses received 0.5 and 0 points, respectively. 
be established for the board of trustees, but also for operational executives, we furthermore argue that well-governed pension funds should define individual management objectives for their CEOs (1) and regularly measure the CEO's performance against those pre-defined objectives $(1)^{19}$. To align CEO interests with the interests of plan members, the MANO Score also assigns 1 point to pension plans whose CEO compensation is linked to the CEO's individual management objectives and/or investment performance. Lastly, in order to be able to effectively deal with conflicts of interest and other governance-related internal issues, a pension fund should have implemented an own written code of conduct to which all bodies involved in the management and oversight process of the pension plan must abide to (1). Existing governance chartas (e.g., such as the ASIP-charta or the OECD guidelines) might thereby be useful as a reference point.

\section{A3) Target Setting and Investment Strategy Score (TSIS)}

A structured investment planning process and a clear target of financing are fundamental prerequisites for superior pension fund performance. The minimum required yield is the return a pension fund needs to achieve on a long-term basis in order to keep its financial balance. AMMANN and ZINGG (2010) describe that the minimum required return net of asset management costs should at least consider guaranteed interest on pension liabilities, longevity risk, accumulation of value fluctuation reserves, and administration costs (1). Since all those parameters can change over time, it might be reasonable to review this minimum yield regularly, at least on an annual basis $(1)^{20}$. To guarantee an optimal portfolio construction process, a pension fund should have realistic expectations about the return and the volatility of its strategic asset allocation $(2)^{21}$. Furthermore, since both the expected return of the strategic asset allocation and the minimum required yield can change over time, the two performance figures should be reviewed against each other on a regular basis (1). To achieve a long-term balance between assets and liabilities, the pension fund's expected policy return ${ }^{22}$ must exceed (or at least be equal to)

19 If a pension fund reported to have no CEO, the maximum achievable points in this sub-score was set to 4 .

20 The Investment Strategy and Target Setting Score assigns 0.5 points if the minimum required yield is reviewed at least biannually and 0 points for no regular reviews.

21 The estimates were deemed realistic if 1 ) the historical mean return of the investment strategy was greater than or equal to the reported expected return and 2) if the historical volatility was lower than or equal to the reported expected volatility of the strategic asset allocation. A $10 \%$ tolerance level was applied.

22 If the expected return was not deemed realistic, the historical mean return was assessed instead. 
the minimum required yield (1). Policy return and asset allocation decisions are frequently taken by the board of trustees in investment strategy meetings. Since such decisions have a substantial impact on the long-term performance of a pension fund, we claim that they should be accompanied by external investment management specialists. Therefore, we reward pension funds that employ independent external experts that participate in investment strategy meetings (1). While a pension fund's strategic asset allocation determines the long-term asset class weights, short-term deviations from the policy structure may theoretically enhance portfolio performance. Empirical evidence on the benefits of tactical asset allocation is contradictory, however. Andonov et al. (2011) find evidence that U.S. defined benefit plans were able to obtain superior performance from intentional changes in their strategic asset allocation and market timing decisions. Other scholars, such as Blake, Lehmann, and Timmermann (1999) or Blake et al. (2013) find counterevidence for British pension schemes. To investigate whether short-term deviations from the strategic allocation are beneficial or detrimental for Swiss pension fund portfolios, the TSIS Score assigns 1 point to funds that pursue active tactical asset allocation (1). Simultaneously, in order to ensure that short-term deviations of asset class weights from the strategic policy do not materially change the longterm investment strategy, we argue that pension fund managers should regularly compare their effective (i.e., realised) portfolio allocation to their strategic asset allocation (1). Potential rebalancing needs can thus be detected in timely manner. Furthermore, in order to be able to respond adequately to structural changes in capital market conditions, a pension fund's management should regularly review its long-term investment strategy, at least on an annual basis.

\section{A4) Investment Process Score (INVP)}

The implementation of the determined investment strategy requires a structured investment process. To follow a systematic portfolio management process, most pension funds have established investment regulations including objectives and general principles, investment guidelines, controlling, accounting, and reporting procedures as well as loyalty regulations in asset management. Since both regulatory and strategic changes may require the revision of established regulations, our Investment Process Score rewards pension funds that review their investment regulations at least on an annual basis $(1)^{23}$. Best practice in asset management furthermore stipulates a high degree of portfolio diversification in order to

23 Pension funds that reported a biannual frequency received 0.5 points on the score. 
reduce idiosyncratic risks. A fundamental pillar in the Swiss occupational pension system is the separation between plan assets and assets of the plan sponsor. Article 57 of the Ordinance on Occupational Old-age, Survivors' and Disability Pension Plans (BVV2) stipulates that non-collateralised investments with the employer must not exceed 5 per cent of plan assets, whereas a number of exceptions apply for collateralised investments. In order to reduce exposure to idiosyncratic employer risks, we reward pension funds that do generally not allocate more than 5 per cent of their assets to employer investments, be it in the form of debt or equity (1).

Decisions about investment style have a substantial impact on a pension fund's performance net of costs. The principles of prudence, diligence, and reasonable care therefore require a detailed investment analysis for each asset class (1). This analysis particularly includes decisions about active versus passive investment approaches, direct versus indirect investing decisions, and the appointment of external investment managers. Such decisions might be efficiently implemented by a chief investment officer with clear responsibilities and execution powers (1).

Occasional events of misconduct and cronyism in assigning mandates to external asset managers by Swiss pension funds have demonstrated the need for objectivity and transparency in the asset manager selection process. To ensure a meritbased assignment of mandates, pension funds should establish explicit selection and dismissal criteria that are objectively quantifiable (1). Investment consultants that assist the manager search can potentially streamline the process by reaping economies in evaluating information $(1)^{24}$. To guarantee unbiased trustee decision-making, we also argue that external asset managers should not participate in investment strategy meetings (1).

In order to avoid conflicts of interest, it has become common practice for institutional investors to assign external asset management mandates based on competitive tendering procedures. While a competitive tendering procedure is not required for occupational pension funds under Swiss law, competition amongst bidding investment managers is likely to benefit pension plan members $(1)^{25}$. Since manager fees reduce the net investment performance at the detriment of beneficiaries, we furthermore argue that well-governed pension funds should regularly re-negotiate, or at least revise, the direct costs of external asset management mandates, at best on an annual basis $(1)^{26}$. Additionally, to avoid significant

24 Goyal and WaHaL (2008) find that investment consultants add value for U.S. small sponsor plans in the form of higher post-hiring manager returns.

25 E.g., in the form of lower costs or better services.

26 For biannual re-negotiations or revisions, we assign 0.5 score points. 
mismatches between assets and liabilities, we hypothesise that it might be beneficial for pension funds to conduct an ongoing asset-liability management, so as to ensure the plan's long-term financial health (1).

\section{A5) Risk Management Score (RIMA)}

Risk management is at the heart of each investment process. The recent financial crisis has highlighted the importance of this discipline particularly. The $O E C D$ Guidelines on Pension Fund Asset Management recommend that pension entities should establish a sound risk management process that measures and appropriately controls a plan's overall portfolio risk profile. In line with this recommendation, we claim that Swiss pension funds should regularly assess their own riskbearing capacity (1) and have a clearly defined risk budget in terms of a maximum value-at-risk or pre-defined stop loss threshold (1). The risks that pension funds bear are manifold. They can be classified into portfolio risks and plan-specific risks. Portfolio risks essentially comprise investment and market risks, default risks, counterparty risks and liquidity risks. Plan-specific risks include funding risks, actuarial, operational, and regulatory risks, as well as the solvency risk of the plan sponsor. Our Risk Management Score thus rewards pension funds whose risk management framework considers all essential portfolio and plan-specific risk factors $(7)^{27}$. Additionally, since those risk factors have different impact magnitudes on pension entities, their potential detrimental effects need to be assessed on a regular basis by using quantitative risk measurement tools ${ }^{28}$. Quantitative assessments of portfolio risk factors should be conducted on both total portfolio level (1) and per asset management mandate (1). In order to account for adverse actuarial and financial market scenarios, we furthermore assert that stress tests might be valuable tools to include in a plan's risk management framework (1). Our RIMA Score moreover assigns 1 point to entities that have established a strategic emergency plan for disaster risks (1). Pre-defined guidelines for violations of tactical fluctuation margins can supplement the risk steering process and prevent excessive deviations from the strategic asset allocation (1). The OECD Guidelines on Pension Fund Asset Management moreover stipulate that pension plans should adequately address currency risks when investing in foreign assets. While investments in foreign currencies may benefit a portfolio in terms of diversification aspects and mean-variance optimisation, we argue that, for general risk

27 Since public pension funds have an implicit state guarantee in a default event, they are not subject to solvency risk of the sponsor. The Risk Management Score accounts for this issue.

28 E.g., such as value-at-risk, volatility of returns, or quantitative tail risk measurement techniques. 
management reasons, pension funds should have established clear and binding rules concerning the management of foreign exchange risks $(1)^{29}$. Such guidelines can include hedging policies and tools as well as explicit weight thresholds for certain currency exposures.

\section{A6) Monitoring and Transparency Score (MOTR)}

Good pension fund governance requires transparency in decision-making as well as ongoing monitoring of investment activities. An effective monitoring process provides objective, decision-relevant information to the board of trustees and enables a timely and systematic measurement of investment performance. To ensure a high degree of objectivity in the investment management process, portfolio performance should be regularly assessed by means of quantitative performance metrics $(1)^{30}$. Quantitative assessment of investment returns should be conducted on both total portfolio level and per asset management mandate in order to obtain a holistic performance picture (1). An independent investment controller who supervises investment actions might support this process (1). Furthermore, comparisons of key performance metrics amongst peer pension plans enables learning from best-performing funds. The Monitoring and Transparency Score therefore assigns 2 points to pension funds that regularly undertake peer group benchmarking regarding administration costs, asset management costs, investment performance and risk structure $(2)^{31}$.

A further key issue in pension fund governance is the avoidance of conflicts of interest of board members. Corporate governance regulations in Switzerland require the disclosure of all board members' mandates in the annual report. We argue that this requirement should also apply to pension funds and claim that all mandates of trustee board members should be disclosed in the annual report $(1)^{32}$. Lastly, new legal regulations following the Minder-Initiative that was passed in March 2013 oblige Swiss pension funds to exercise their shareholder voting rights of portfolio stocks at the companies' annual general meeting. To exercise the rights in the best interests of plan beneficiaries, we stipulate that pension funds should have established a comprehensive information concept for the

29 Article 55e BVV2 requires Swiss pension funds to not invest more than 30 per cent of total plan assets in unhedged foreign currency assets.

30 E.g., such as Jensen's alpha, Sharpe ratio, information ratio, etc.

31 For each element, the score assigns 0.5 points.

32 E.g., such as other trustee board mandates or corporate supervisory board mandates, political offices, etc. 
plan members regarding the exercise of their voting rights (1). Lastly, in order to facilitate access to information and hence foster transparency for all stakeholder groups, we argue that a pension fund's annual report should be made available to the general public online (1).

\section{References}

Albrecht, W., Shamshub, H., and Giannatasio, N. A. (2007), "Public Pension Fund Governance Practices and Financial Performance", Journal of Public Budgeting, Accounting \& Financial Management, 19(2), pp. 245-267.

Ambachtsheer, K. P., Capelle, R., and Lum, H. (2008), "The Pension Governance Deficit: Still with Us", Rotman International Journal of Pension Management, 1(1), pp. 14-21.

Ambachtsheer, K. P., Capelle, R., and Scheibelhut, T. (1998), "Improving Pension Fund Performance", Financial Analysts Journal, 54(6), pp. 15-21

Ambachtsheer, K. P., and Ezra, D. D. (1998), Pension Fund Excellence: Creating Value for Shareholders, New York: John Wiley \& Sons.

Ammann, M., Oesch, D., and Schmid, M. (2011), "Corporate Governance and Firm Valuation: International Evidence", Journal of Empirical Finance, 18 , pp. 36-55.

Ammann, M., Oesch, D., and Schmid, M. (2013), "Product Market Competition, Corporate Governance, and Firm Value: Evidence from the EU-Area", European Financial Management, 19(3), pp. 209-250.

Ammann, M., and ZingG, A. (2010), "Performance and Governance of Swiss Pension Funds", Journal of Pension Economics and Finance, 9(1), pp. 95-128. Andonov, A., Bauer, R., and Cremers, M. (2011), "Can Large Pension Funds Beat the Market? Asset Allocation, Market Timing, Security Selection and the Limits of Liquidity", Maastricht and Yale University Working Paper.

Bebchuк, L., and Cohen, A. (2005), "The Costs of Entrenched Boards", Journal of Financial Economics, 78, pp.409-433.

Bebchuk, L., Cohen, A., and Ferrell, A. (2008), "What Matters in Corporate Governance?”, Review of Financial Studies, 22(2), pp. 783-827.

Blake, D., Lehmann, B. N., and Timmermann, A. (1999), "Asset Allocation Dynamics and Pension Fund Performance", Journal of Business, 72(4), pp. 429-461.

Blake, D., Timmermann, A., Rossi, A. G., Tonks, I., and Wermers, R. (2013), "Decentralized Investment Management: Evidence from the Pension Fund Industry", Journal of Finance, 68(3), pp. 1133-1178. 
Brown, L. D., and Caylor, M. L. (2006), "Corporate Governance and Firm Valuation", Journal of Accounting and Public Policy, 25, pp.409-434.

Clapman, P. (2007), "Committee on Fund Governance - Best Practice Principles", Discussion Paper at the Stanford Institutional Investors' Forum.

Clark, G. L. (2004), "Pension Fund Governance: Expertise and Organisational Form”, Journal of Pension Economics and Finance, 3(2), pp. 233-253.

Clark, G. L. (2007), "Expertise and Representation in Financial Institutions: UK Legislation on Pension Fund Governance and US Regulation of the Mutual Fund Industry", $21^{\text {st }}$ Century Society: Journal of the Academy of Social Sciences, 2(1), pp. 1-24.

Clark, G. L., Caerlewy-Smith, E., and Marshall, J. C. (2006), "Pension Fund Trustee Competence: Decision-Making in Problems Relevant to Investment Practice", Journal of Pension Economics and Finance, 5(1), pp. 91-110.

Clark, G. L., and Urwin, R. (2008), "Best-Practice Pension Fund Governance", Journal of Asset Management, 9(1), pp. 2-21.

Clark, G. L., and Urwin, R. (2010), "Innovative Models of Pension Fund Governance in the Context of the Global Financial Crisis", Pensions, 15(1), pp. 62-77.

Gompers, P., IshiI, J., and Metrick, A. (2003), "Corporate Governance and Equity Prices", The Quarterly Journal of Economics, 118(1), pp. 107-155.

Goyal, A., and Wahal, S. (2008), "The Selection and Termination of Investment Management Firms by Plan Sponsors", Journal of Finance, 63(4), pp. $1805-1847$.

Hess, D. (2005), "Protecting and Politicizing Public Pension Fund Assets: Empirical Evidence on the Effects of Governance Structures and Practices", University of California, Davis Law Review, 39, pp. 187-227.

Harper, J. T. (2008), "Public Sector Pension Governance in the United States: Up to the Task?", Rotman International Journal of Pension Management, 1(1), pp. 22-28.

Impavido, G. (2002), "On the Governance of Public Pension Fund Management", World Bank Policy Research Working Paper Series 2878.

Jackowicz, K., and Kowalewski, O. (2012), "Crisis, Internal Governance Mechanisms and Pension Fund Performance. Evidence from Poland", Emerging Markets Review, 13(1), pp.493-515.

Jensen, M. C. (1986), "The Performance of Mutual Funds in the Period 19451964", Journal of Finance, 23 (1968), pp. 389-416.

Jensen, M. C. (1993), "The Modern Industrial Revolution, Exit, and the Failure of Internal Control Systems", Journal of Finance, 48(3), pp. 831-880. 
Kanagaretnam, K., Lobo, J., and Whalen, J. (2007), “Does Good Corporate Governance Reduce Information Asymmetry Around Quarterly Earnings Announcements?", Journal of Accounting and Public Policy, 26(4), pp.497-522. Lipton, M., and Lorsch, J. W. (1992), "A Modest Proposal for Improved Corporate Governance", Business Lawyer, 48(1), pp. 59-77.

Mitchell, O. S., and Hsin, P.-L. (1997), "Public Sector Pension Governance and Performance", in The Economics of Pensions: Principles, Policies, and International Experience, S. Valdés-Prieto, ed., pp. 92-126, Cambridge: Cambridge University Press.

OECD (2006), "OECD Guidelines on Pension Fund Asset Management", OECD Policy Guidelines.

OECD (2011), "OECD/IOPS Good Practices for Pension Funds' Risk Management Systems”, OECD Policy Guidelines.

OECD (2009), "OECD Guidelines on Pension Fund Governance", OECD Policy Guidelines.

Swiss Federal Statistical Office (2015), "Results of the Pension Fund Statistic", BFS Website.

Swiss Federal Statistical Office (2014), Die berufliche Vorsorge in der Schweiz - Kennzablen der Pensionskassenstatistik 2006-2012, Neuchâtel: Bundesamt für Statistik.

Wright, M., Siegel, D. S., Keasey, K., and Filatotchev, I. (2013), The Oxford Handbook of Corporate Governance, Oxford: Oxford University Press.

Yang, T., and Mitchell, O. S. (2008). "Public Pension Governance, Funding, and Performance: A Longitudinal Appraisal", in Pension Fund Governance: A Global Perspective, J. Evans \& J. Piggot, eds., pp. 179-199, London: Edward Elgar.

Yermo, F., and Stewart, J. (2008), "Pension Fund Governance - Challenges and Potential Solutions", OECD Working Papers on Insurance and Private Pensions No. 18. 